\title{
PERSPECTIVES ON CHOICE OF LAW FOR CORPORATE INTERNAL AFFAIRS
}

\author{
Deborah A. DeMotT*
}

\section{INTRODUCTION}

Some legal rules appear to have an almost irresistible intuitive appeal or force of logic. To many corporate lawyers, the "internal affairs" doctrinethe notion that only one state, almost always the site of incorporation, should be authorized to regulate the relationships among a corporation and its officers, directors, and shareholders-is irresistible if not logically inevitable. Convenience and predictability of application, it is said, ${ }^{1}$ dictate that one body of corporate law govern internal affairs, while the most plausible state to supply that law is the state of incorporation, to whose legislative grace the corporation owes its legal existence. ${ }^{2}$ The identity of that state is, after all, more readily ascertainable and more constant than other states with which the corporation and its constituents may have entanglements.

There is another long standing perspective on this question and other related issues, however. An observation in Justice Marshall's opinion for the majority in Shaffer $v$. Heitner, ${ }^{3}$ a case best known for its impact on permissible

Copyright (c) 1985 by Law and Contemporary Problems

* Professor of Law, Duke University School of Law. I am grateful to Simon M. Lorne, Esq., for his comments on an early version of this manuscript.

1. See, e.g., Reese \& Kaufman, The Law Governing Corporate Internal Affairs: Choice of Law E the Impact of Full Faith and Credit, 58 Colum. L. REv. 1118,1125 (1958); Ratner \& Schwartz, The Impact of Shaffer v. Heitner on the Substantive Law of Corporations, 45 BrookLyN L. Rev. 641 , 669 (1979); cf. Kirgis, The Roles of Due Process and Full Faith Credit in Choice of Law, 62 Cornell L. Rev. 94, 139-42 (arguing that even where uniformity of rule is necessary, state of incorporation need not be the bellwether).

2. Another possible source of such law is federal law, were Congress to enact a federal incorporation statute. See infra note 191 and accompanying text. The ramifications of such a move transcend the modest scope of this essay.

3. 433 U.S. 186 (1977). In Shaffer, the Court held that a state's attempt to assert jurisdiction over a nonresident defendant must be evaluated against the minimum contacts standard articulated in International Shoe v. Washington, 326 U.S. 310 (1945). Delaware compelled the presence of defendants through its sequestration process, which enabled the seizure of shares of stock owned by defendants in a Delaware company. The fact that the stock certificates were not present in Delaware was not an obstacle to this process because by statute Delaware defined itself to be the situs of ownership of all stock in Delaware corporations. 433 U.S. at 192. Defendants were notified by mail and by publication of the fact of sequestration. Id. The Court held that the statutorily defined presence of defendants' property in Delaware was an insufficient contact with the state to support the assertion of jurisdiction and that the Delaware legislature had failed to assert explicitly that defendants' other contacts with the state (such as their positions as officers and directors of a Delaware corporation) constituted a basis for the exercise of personal jurisdiction. Delaware has since enacted such a statute reaching corporate directors but not officers or shareholders. See Del. Code AnN. tit. 10, § 3114 (Supp. 1982). 
grounds for personal jurisdiction, suggests the alternative perspective. Appellants in the case, nonresident directors of a Delaware corporation whose headquarters were situated elsewhere, challenged the constitutionality of Delaware's sequestration procedure. Justice Marshall wrote, "[a]ppellants have simply had nothing to do with the State of Delaware."4 Technically, this point is mistaken, as surely the corporation's directors were responsible for or at least aware of the choice to incorporate in Delaware. Nevertheless, the directors' relationship with Delaware was confined to the legal fact of the company's incorporation there, and to some the overall insignificance of that fact may have the same intuitive and irresistible force as does the internal affairs doctrine to others. To be sure, when the subject matter of the litigation concerns some matter other than the corporation's internal affairs, the site of incorporation fades from insignificance to complete irrelevance. For example, the fact of Delaware incorporation does not constrain the law applicable to torts committed or contracts with third parties entered into by Delaware corporations. ${ }^{5}$ As this article later illustrates, the view that the state of incorporation is relatively insignificant to internal affairs questions as well has found many expressions, most notably in those state statutes that, as an exercise in statutory outreach, mandate the application of local law to specified internal affairs questions for certain foreign corporations.

The outreach statutes, along with the case law that achieves a similar result, represent a counterculture to the mainstream choice of law approach that has wholeheartedly embraced the internal affairs doctrine. The mainstream approach is epitomized by the view expressed in the Restatement (Second) of Conflict of Laws: "[a]pplication of the local law of the state of incorporation will usually be supported by those choice-of-law factors favoring the needs of the interstate and international systems, certainty, predictability and uniformity of result, protection of the justified expectations of the parties and ease in the application of the law to be applied." 6 This article explores the consequences of the decision to substitute, partially or wholly, for an unswerving adherence to the internal affairs doctrine, other tactics for fixing the law applicable to internal affairs questions. The article identifies a counterculture among corporation statutes to which these departures from the internal affairs rule largely correspond. In addition, the article considers conflicts among corporation statutes over internal affairs matters. It concludes by examining the constitutionality of the application of local law to the internal affairs of foreign corporations from the perspective of the commerce and full faith and credit clauses.

4. Shaffer, 433 U.S. at 216.

5. See Restatement (Second) of Conflict of Laws $\$ 301$ (1971) (corporation's rights and liabilities regarding third parties as to acts that could be done by an individual determined by choice of law principles applicable to noncorporate persons).

6. Id. $\S 302$ comment $\mathrm{e} ; c f . i d$. $\S 303$ comment $\mathrm{d}$ (stressing importance of uniform treatment of shareholders). 


\section{Statutory Landscapes and Case Law Developments}

Most states follow the traditional internal affairs doctrine, either through case law or statutory provisions. About half of the states have enacted provisions derived from the language of section 106 of the Model Business Corporation Act, which provides:

A foreign corporation shall not be denied a certificate of authority by reason of the fact that the laws of the state or country under which such corporation is organized governing its organization and internal affairs differ from the laws of this State, and nothing in this Act contained shall be construed to authorize this State to regulate the organization or the internal affairs of such corporation. ${ }^{7}$

While the language preceding the comma prohibits the state from discriminating among foreign corporations in granting authorizations to do business within the state, the language following the comma neatly encapsulates the internal affairs doctrine.

Some states that have enacted provisions based on section 106, including Connecticut, ${ }^{8}$ Louisiana, ${ }^{9}$ and North Carolina, ${ }^{10}$ nevertheless have not enacted the language after the comma. Although the statutes of these states do not expressly require the application of any of these states' internal affairs provisions to foreign corporations, and thus do not have an expressly outreaching effect, the statutes do not prohibit such application. Apparently, this omission was not inadvertent, at least in the case of New Jersey. The New Jersey Commissioners' Comment to the statutory language that contains this omission" states that "the Commission intentionally departed from the 'hands off' approach of [Model Business Corporation Act section 106] which, had it been adopted, might have appeared to deny any authority whatever to this State under this Revision to regulate the internal affairs of a foreign corporation."12 As a consequence,

[New Jersey's] courts remain free under this Revision . . . to retain jurisdiction in cases involving the internal affairs of a foreign corporation and to grant relief on equitable principles whenever indicated, even to the extent of applying to a foreign corporation in a proper case certain substantive features of this Revision. ${ }^{13}$

Unfortunately, the Commissioners did not specify which features of the statute should be so applied, and the subsequent New Jersey case law has not pursued the invitation to apply local law.

As the New Jersey comment intimates, in a much earlier era the "internal affairs" problem was seen as one of jurisdiction rather than choice of law; courts were once thought to lack jurisdiction over actions involving the internal affairs of foreign corporations. ${ }^{14}$ Once the jurisdictional impediment

7. Model Business CoRp. ACt $\$ 106$ (1971).

8. Conn. Gen. Stat. Ann. § 33-396 (1960).

9. La. Rev. Stat. AnN. \& 12:301 (1969).

10. N.C. Gen. Stat. \$55-131(a) (1982).

11. N.J. STAT. AnN. \$14A:13-2(2) (West 1969).

12. See id. Commissioners' Comment.

13. Id.

14. See Latty, Pseudo-Foreign Corporations, 65 YAlE L. J. 137, $144-45$ (1955). 
fell, the question became whether a court should keep jurisdiction of an internal affairs case or dismiss under the rubric of forum non conveniens. ${ }^{15}$ Thus, only when these initial hurdles are passed does there arise the question of what is the appropriate substantive law to be applied to internal affairs issues that an action presents.

Some states have adopted statutory language that appears to be consistent with the internal affairs doctrine, but this language does not expressly or impliedly mandate the doctrine's application. For example, while Delaware law has no counterpart to section 106 prohibiting its courts from applying Delaware law to the internal affairs of foreign corporations, section 121(b) of Delaware's General Corporation Law provides that "[e]very corporation shall be governed by the provisions and be subject to the restrictions and liabilities contained in this chapter." 16 The statute thus directs that Delaware law be applied to Delaware corporations, a directive presumably applicable not only to Delaware courts but to courts of other jurisdictions as well. In some respects, this requirement in the statute is unremarkable, for it is unlikely that any state would express manifest disinterest in the law applicable to corporations created pursuant to its corporation statute.

Two states, New York and California, have statutes that are explicitly outreaching. These statutes expressly mandate the application of local law to specified internal affairs questions in certain foreign corporations. The New York statute makes applicable to foreign corporations doing business within the state its provisions granting inspection rights to shareholders ${ }^{17}$ and its provisions prescribing directors' liability for neglecting or otherwise violating their duties to the management of the corporation's affairs ${ }^{18}$ and for authorizing illegal dividends, ${ }^{19}$ illegal stock repurchases ${ }^{20}$ and illegal loans. ${ }^{21}$ In addition, the provisions in the New York statute dealing with indemnification and insurance for directors and officers, ${ }^{22}$ imposing special requirements on derivative litigation (including the security for expense requirement), ${ }^{23}$ and regulating mergers and consolidations ${ }^{24}$ are expressly made applicable to such foreign corporations. Foreign corporations are exempt from all of these provisions if their shares are listed on a national

15. See id.

16. Del. Code AnN. tit. 8, § 121 (b) (1983).

17. N.Y. Bus. CORP. LAW $\$ 1315$ (a) (McKinney 1963) (granting right to examine shareholders' list). This right is made available only to New York residents who are shareholders of record of at least five percent of any class of outstanding shares. The right to examine may be denied if the stockholder fails to furnish an affidavit stating that inspection "is not desired for a purpose which is in the interest of a business or object other than the business of the foreign corporation" and that the shareholder has not sold or offered to sell, or aided and abetted a sale, of a shareholder list within the past five years. Id. $\S 1315$ (b) (McKinney $1963 \&$ Supp. 1983-84).

18. N.Y. Bus. Corp. Law $\S 1317$ (a) (McKinney 1963).

19. Id.

20. Id.

21. Id.

22. Id. § 1319(4) (McKinney 1983).

23. Id. $\$ 1319(3),(4)$.

24. Id. $\S 1319(6)$. 
securities exchange or if less than one half of the corporation's business income during the preceding fiscal year was allocable to New York for franchise tax purposes. ${ }^{25}$

The California statute, in contrast, although less expansive in the range of foreign corporations to which it applies, requires conformity with a more extensive range of internal affairs provisions. Section 2115 of the California Corporations Code defines the foreign corporations for which the California statute has an outreach effect as those foreign corporations, half of whose voting securities are held of record by persons with California addresses, that also conduct half of their business in California as measured by a formula weighing assets, sales and payroll factors. ${ }^{26}$ Foreign corporations whose securities are listed on a national stock exchange certified by the California Commissioner of Corporations are exempt, however, as is a corporation if all of its voting shares are owned by a corporation not subject to section 2115.27

Nonexempt foreign corporations falling within the outreach effect of the California statute are subject to a fairly broad range of internal affairs provisions. Among these internal affairs provisions are those provisions requiring the annual election of all directors, providing that shareholders have the right to vote their shares cumulatively in such elections, permitting the removal of directors without cause, and specifying directors' duties to the corporation. ${ }^{28}$ In addition, foreign corporations within the section 2115 definition are also subject to the California provisions that limit corporate indemnification of officers and directors, that regulate mergers, reorganizations and sales of assets, and that grant rights to stockholders who dissent from specified corporate transactions. ${ }^{29}$ Section 2115 also makes applicable to these foreign corporations the Code provisions defining shareholders' rights to inspect, ${ }^{30}$ to obtain a list of shareholders, ${ }^{31}$ and to receive annual reports from the corporation. ${ }^{32}$ The inspection and reporting sections themselves, moreover, contain outreach provisions making the requirements of the sections applicable to an even broader range of foreign corporations than that included in the section 2115 definition. As a result, the inspection and reporting sections apply to foreign corporations having principal executive offices in California or customarily holding board

25. Id. $\S 1320$ (a). The term "national securities exchange" is not defined by the statute. Section 19(a) of the Securities Exchange Act of 1934, however, provides for registration as a national securities exchange with the Securities and Exchange Commission. 15 U.S.C. $\S 78 s(a)(1)(1981)$.

26. Cal. Corp. Code $\S 2115$ (a) (1977 \& Supp. 1984).

27. Id. $\S 2115(\mathrm{e})$. The securities exchanges that have been certified by the commissioner are the American, New York, and Pacific Stock Exchanges. See Cal. Admin. Reg. \$260.101.2, reprinted in 2 Corp. Current Statutes (P-H) at 262 (effective Oct. 18, 1979).

28. Cal. Corp. Code $\S 2115$ (b) (1977\& Supp. 1984).

29. Id.

30. Id.; see id. $\$ 1601$ (1977). Section 1602 grants a similarly absolute right to corporate directors to inspect corporate books and records. Id. $\S 1602$.

31. Id. $\S 2115$ (b); see id. $\S 1600$ (1977 \& Supp. 1984). Section 1600 (a) states that the right to obtain a shareholder list is "absolute," unlike the New York provision that limits the shareholders' right to obtain a shareholder list to those shareholders with appropriate purposes. See supra note 17.

32. Cal. Corp. Code $\S 2115$ (b) (1977 \& Supp. 1984); see id. $\$ 1501$. 
meetings within the state, independent of the amount of business derived from California sources or the number of shareholders residing in California. ${ }^{33}$

Enforcement of the outreach provisions of the California statute is furthered by two provisions. Section 2108 requires that all foreign corporations qualified to do business in California or subject to section 2115 file an annual statement detailing the percentage of their stockholders who reside in California and the extent of their California-source income. ${ }^{34}$ The Secretary of State may forfeit a foreign corporation's right to do business within California if this statement is not filed after notice of failure to file has been given. ${ }^{35}$ Section 1508 permits California's Attorney General to institute, maintain or intervene in suits alleging that a foreign or domestic corporation has failed to comply with certain portions of the Code, including the annual meeting and cumulative voting requirements. ${ }^{36}$

In contrast to the certainty with which the state of incorporation may be determined, the criteria upon which the applicability of section 2115 hinges are not constants. For example, whether half of a corporation's business is derived from California and whether half of its voting securities have record holders with California addresses may well vary from year to year (and indeed throughout any given year). Thus, a corporation might be subject to section 2115 one year but not the next, depending on its situation at the time of filing the annual statement required by section 2108 .

Both the New York and California statutes mandate the application of local law to foreign corporations that could have significant economic connections with states other than New York and California. Although some authorities have advocated the application of local law to the internal affairs of foreign corporations, they emphasize primarily the "pseudo-foreign" corporation: one whose existence, apart from the legal fact of foreign incorporation, is confined to one state. ${ }^{37}$ "Pseudo-foreign" corporations are enterprises "essentially local in character" whose business and personnel are predominantly identified with one state ${ }^{38}$ Their out-of-state incorporation makes them "tramp corporations," it is occasionally said, ${ }^{39}$ in contexts in which this description connotes a carpetbagger or scofflaw rather than a corporate Huckleberry Finn. In any event, the New York and California outreach provisions are not confined to such "tramp corporations" and

33. See id. $\$ \S 1501(\mathrm{~g}), 1600(\mathrm{~d}), 1601(\mathrm{a})$.

34. Id. § 2108 (a) (1977).

35. Id. \& $2108(\mathrm{~d})$.

36. Id. § 1508 .

37. See Latty, supra note 14. In contrast, the "quasi-foreign" corporation, although its ties to the state of incorporation consist solely of the fact of incorporation, does business in two or more states and has ties with two or more states that are substantially equivalent. See Kaplan, Forégn Corporations and Local Corporate Policy, 21 VAND. L. Rev. 433, 439 (1968).

38. See Latty, supra note 14 , at 137.

39. See, e.g., Oldham, Califormia Regulates Pseudo-Foreign Corporations-Trampling Upon the Tramp, 17 Santa Clara L. Rev. 85 (1977). 
clearly apply to some corporations with real economic existences in other states.

In contrast to New York and California, other states have less aggressive outreach provisions that, although purporting to apply local law to the internal affairs of foreign corporations, do so in less systematic or expansive fashion. A few states, for example, make statutory assertions that foreign corporations, as to contracts made or business done within the state, shall be subject to the same liabilities, limitations and regulations as companies incorporated within the state, and shall enjoy no greater privileges or powers than the state's own corporations. ${ }^{40}$ Depending on a court's willingness to construe "doing business" to include internal affairs activities such as holding shareholder meetings within the state, these statutes may support the legitimacy of regulation through local law. The Maryland corporation law contains a provision of potentially broader scope; it asserts that "[b]y doing intrastate, interstate, or foreign business in this State, a foreign corporation assents to the laws of this State." 41 No case law reveals how broad the legislature intended this assent to be. In particular, it is unclear whether this assent extends to the entirety of Maryland's corporation statute. Finally, Texas adopted the language of section 106 of the Model Business Corporation Act in its entirety, but qualified its statute with the proviso that "nothing in this act contained shall be construed to authorize this State to regulate the organization of such corporation or its internal affairs not intrastate in Texas." 42 One leading authority has suggested that this proviso might be combined with another section of the statute subjecting officers and directors of foreign corporations to the same "duties, restrictions, penalties and liabilities" as their Texas counterparts ${ }^{43}$ to mean that internal affairs activities may be regulated by the full range of provisions in the Texas corporation statute. ${ }^{44}$

The divergence in statutory approaches to the internal affairs question is paralleled by a richly varied body of case law. In some states, of course, courts have consistently adhered to the internal affairs doctrine, departing from it only when the foreign corporation had no contacts with its state of incorporation other than the legal fact of its organization under that state's corporation statute. In other jurisdictions, however, at least as to some internal affairs issues, courts have taken a more expansive view of the applicability of local law to foreign corporations. These courts have taken jurisdiction over such cases and have applied local law to resolve disputes

40. See, e.g., Al.A. Code § 10-2A-227 (1984); Ark. Const. art. XII, § 11. However, Alabama has also adopted language comparable to Model Business Corp. ACT $\$ 106$ (1971). See Ala. Code $\$ 10$ 2A-226 (1984).

41. See Mo. Corps. \& Ass'ns Code Ann. \& 7-105 (1975).

42. See Tex. Stat. ANn. art. 1396-8.01 (Vernon 1979) (emphasis added).

43. Id. art 1396-8.02.

44. See Latty, Some Miscellaneous Novelties in the New Conporation Statutes, Law \& Contemp. Probs., Spring 1958, at 363, 397. 
about such quintessentially internal matters as shareholders' inspection rights, dividend practices, elections, and directors' liability to the corporation.

The inspection cases use a variety of rationales to justify the application of forum-state law. Some older cases reason simply that a shareholder's right to inspect books and records is guaranteed by the common law and permit the inspection of a foreign corporation's books and records on that basis alone. ${ }^{45}$ More recent cases have used the more elaborate rationale that a foreign corporation, by entering a state and doing business in it, impliedly accepts the conditions placed by local law upon doing business in the state, including requirements that corporate books and records be made available for inspection. ${ }^{46} \mathrm{~A}$ few cases have supplemented this reasoning with the corollary argument that no foreign corporation has rights or privileges superior to those granted to similar domestic corporations. ${ }^{47}$ Some courts also examine whether the plaintiff would be without remedy if the relief requested were not given. ${ }^{48}$ Finally, some courts simply assert that disputes over inspection do not involve internal affairs, thereby pretermitting the question of the internal affairs doctrine. ${ }^{49}$

One aspect of the inspection cases that is a common theme in all internal affairs cases involving foreign corporations is the issue of the tribunal's ability to grant effective relief and award an enforceable decree. Obviously, a serious

45. See, e.g., Nettles v. McConnell, 151 Ala. 538, 43 So. 838 (1907); State ex rel. Gilbert, Eliott \& Co. v. Lake Torpedo Boat Co., 90 Conn. 638, 98 A. 580 (1916); Wise v. H.M. Byllesby \& Co., 285 Ill. App. 40, I N.E.2d 536 (1936); Klotz v. Pan-American Match Co., 221 Mass. 38, 108 N.E. 764 (1915); Andrews v. Mines Corp., 205 Mass. 121, 91 N.E. 122 (1910); Sanders v. Pacific Gamble Robinson Co., 250 Minn. 265, 84 N.W.2d 919 (1957); State ex rel. English v. Lazarus, 127 Mo. App. 401, 105 S.W. 780 (1907); Siravo v. Sirian Lamp Co., 124 N.J.L. 433, 12 A.2d 682 (1940); State ex rel. Grismer v. Merger Mines Corp., 3 Wash. 2d 417, 101 P.2d 308 (1940). But of. Clark v. Mutual Reserve Fund Life Ass'n, 14 App. Cas. 154, 43 L.R.A. 390 (D.C. 1899); Commonwealth ex rel. Kinney v. Mexican Plantation Co., 19 Pa. D. 861 (1910), overruled by Conerty v. Butler County Oil Refining Co., 301 Pa. 417, 152 A. 672 (1930); Taylor v. Mutual Reserve Fund Life Ass'n, 97 Va. 60, 33 S.E. 385 (1899) (court refused to take jurisdiction of action involving internal affairs of foreign corporation).

46. See, e.g., Loveman v. Tutwiler Inv. Co., 240 Ala. 424, 199 So. 854 (1941); People ex rel. Hollingshead v. American Discount Co., 332 Ill. 18, 163 N.E. 479 (1928); McCormick v. Statler Hotels Del. Corp., 55 Ill. App. 2d 21, 203 N.E.2d 697 (1964); State ex rel. Watkins v. North Am. Land \& Timber Co.. 106 La. 621,31 So. 172 (1902); State ex rel. Smalley v. Sterns Tire \& Tube Co., 202 S.W. 459 (Mo. App. 1918); American Shipbuilding Co. v. Whitney, 19 Ohio C.C. (n.s.) 584, 36 Ohio C.C. 668, rev 'd on other grounds, 14 Ohio N.P. (n.s.) 12, 23 Ohio Dec. 1 (1912); Toklan Royalty Corp. v. Tiffany, 193 Okla. 120, 141 P.2d 571 (1943): State ex rel. Quinn v. Thompson's Malted Food Co., 160 Wis. 671,152 N.W. 458 (1915)

47. See. e.g.. People ex rel. Hollingshead v. American Discount Co., 332 Ill. 18, 23, 163 N.E. 479, 481-82 (1928); State ex rel. Smalley v. Sterns Tube \& Tire Co., 202 S.W. 459, 459-60 (Mo. App. 1918): American Shipbuilding Co. v. Whitney, 19 Ohio C.C. (n.s.) 584, 585, 36 Ohio C.C. 668,669 70, rec'd on other grounds. 14 Ohio N.P. (n.s.) 12, 23 Ohio Dec. 1 (1943); Toklan Royalty Corp. v. Iiffany. 193 Okla. 120, 122, 141 P.2d 571, 573-74 (1943); State ex rel. Quinn v. Thompson's Malted Food Co., 160 Wis. 671, 674, 152 N.W. 458, 459 (1915).

48. Sep. p.g. Nettles v. McConnell, I51 Ala. 538, 542, 43 So. 838, 839 (1907); State ex rel. Richardson v. Suift, 7 Houst. 137, 152, 30 A. 781, 783 (Del. Super. Ct. 1885), affd, 12 Del. 338, 6 A. 856 (1886); Appleton v. Worne Plastics Corp., 140 N.J. Eq. 324, 330-31, 54 A.2d 612, 616-17 (N.J. (h. 1947).

49. Sep, e.g., State ex rel. Gilbert, Eliott \& Co. v. Lake Torpedo Boat Co., 90 Conn. 638, 642, 98 A. 580. 581 (1916): McCormick v. Statler Hotels Del. Corp., 55 III. App. 2d 21, 34, 203 N.E.2d 697, 703 (1964); Kahn v. American Cone \& Pretzel Co., 365 Pa. 161, 164, 74 A.2d 160, 162 (1950); Polakoff v. Marchand College of Chiropractic, 8 Pa. D. \& C. 71, appeal quashed, 287 Pa. 28, 134 A. 529 (1926). 
difficulty arises when enforcement of the court's order would require extraterritorial action. Indeed, the practical significance of the "outreach" statutes may be a function, first, of whether jurisdiction over the defendants is available in the state with such a statute, and, second, of whether any other state would give effect to the outreach statute if jurisdiction over the defendants is available only in that other state. ${ }^{50}$

In most of the inspection cases, courts carefully emphasize that the inspection rights created by local law apply only to those books and records within their respective jurisdictions. ${ }^{51}$ In a few cases, courts ordered inspection of books and records not then within their jurisdiction that previously had been within the state. ${ }^{52}$ In the remarkable Pennsylvania case of Tierney v. Indian Ridge Coal E Coke Co., however, the court applied local law to compel inspection of the books and records of a West Virginia corporation despite the fact that the corporation maintained no office and did no business in Pennsylvania. ${ }^{53}$ In that case, some of the corporation's officers resided in Pennsylvania (where they kept copies of some of the corporate records) and used a Pennsylvania bank to keep some corporate accounts. ${ }^{54}$ The court apparently relied upon these contacts to compel inspection even though there was no showing that the plaintiff would otherwise be without a remedy.

Relatively few cases apply local law to dividend disputes in foreign corporations, perhaps because the question of whether to declare a dividend is, with the exception described below, relegated to the business judgment of the corporation's directors if the corporation's financial health meets basic tests established by statute. Unlike the prescription of shareholders' inspection rights, the regulation of dividends may affect the interests of the corporation's creditors as well as those of its internal constituencies and may thus implicate the interests of the state in protecting the contractual expectations of its citizens as the foreign corporation's creditors. On the other hand, although a corporation's creditors undoubtedly have an interest in preserving its assets against inordinate dividend payments, intracorporate relationships are also affected by dividend policies. The directors' judgments about dividends define economic prerogatives of the common stockholders in relation to any preferred shares; further, by statute, apart from the contractually defined claims of preferred stock, directors' business judgments about dividend matters are generally not amenable to stockholder challenge.

50. See infra text accompanying notes 177-78.

51. See, e.g., Loveman v. Tutwiler Inv. Co., 240 Ala. 424, 426, 199 So. 854, 856 (1941); Nettles v. McConnell, 151 Ala. 538, 545, 43 So. 838, 840 (1907); McCormick v. Statler Hotels Del. Corp., 55 Ill. App.2d 21, 33-34, 203 N.E.2d 697, 703 (1964); State ex rel. Watkins v. North Am. Land \& Timber Co., 106 La. 621 , 633-34, 31 So. 172, 177 (1902); Andrews v. Mines Corp., 205 Mass. 121, 123, 91 N.E. 122, 123 (1910); Appleton v. Worne Plastics Corp., 140 N.J. Eq. 324, 330-31, 54 A.2d 612,617 (N.J. Ch. 1947); Donna v. Abbotts Dairies, Inc., 399 Pa. 497, 161 A.2d 13 (1960); Tierney v. Indian Ridge Coal \& Coke Co., 256 Pa. 340, 341, 100 A. 814, 815 (1917); Polakoff v. Marchand College of Chiropractic, 8 Pa. D. \& C. 71, 72, appeal quashed, 287 Pa. 28, 134 A. 529 (1926).

52. See, e.g., Lonergan v. Crucible Steel Co. of Am., 37 Ill. 2d 599. 229 N.E.2d 536 (1967);

People ex rel. Hollingshead v. American Discount Co., 332 Ill. 18, 26, 163 N.E. 479, 483 (1928).

53. See Tierney v. Indian Ridge Coal \& Coke Co., $256 \mathrm{~Pa} .340,341,100$ A. 814,815 (1917).

54. See id. 
In International Harvester Co. v. Wisconsin Department of Taxation, the dispute concerned Wisconsin's right, through its "dividend privilege" tax, to tax or otherwise regulate dividends paid to shareholders out of earnings derived from Wisconsin sources. ${ }^{55}$ The Supreme Court held that "Wisconsin may impose a measure of control upon the corporation there with respect to withdrawal of its earnings from the state, and also may, for protection of the interests of the state and of its citizens, regulate to some extent the declaration and distribution of dividends by a foreign corporation, certainly with respect to Wisconsin earnings." 56 Justice Jackson's dissent argued that Wisconsin was, through the allocation of earnings in its tax scheme between common and preferred stock, altering "the purely internal relations of different classes of stockholders without in the least affecting their relation to creditors." 57

A more provocative, albeit hypothetical, instance of outreaching dividend regulation arises under an unusual provision in the North Carolina corporate statute entitling a twenty percent stockholder in a close corporation to compel the declaration and payment of a dividend from earnings under some financial circumstances. ${ }^{58}$ In light of the fact that North Carolina is also a state that has from time to time taken a generous view of its ability to regulate the internal affairs of foreign corporations, ${ }^{59}$ it is possible that a court might determine that the statute's unusual mandatory dividend right should be made available to North Carolina stockholders in a foreign corporation.

Disputes over the election of directors involve corporate "internal affairs" in a fashion more obviously exclusive of the interests of creditors and the state than do disputes over dividend payments. This fact, however, has not prevented courts from taking jurisdiction over cases litigating election disputes in foreign corporations and applying local law to resolve the election contest. Most of the cases involve the use of local mandamus statutes to compel a director to relinquish his office and any corporate papers to his successor. ${ }^{60}$ While in most such instances the court appears to have been merely enforcing a right already determined by the law of the state of incorporation, the court was moved to act by what it perceived to be a lack of remedy in the state of incorporation. The failure of remedy arose because the state of incorporation lacked jurisdiction over the offending party who refused to relinquish his office and turn over the corporation's books and records to his successor. ${ }^{61}$

55. See International Harvester Co. v. Wisconsin Dep't of Taxation, 322 U.S. 435 (1944).

56. Id. at 442.

57. Id. at 449 (Jackson, J., dissenting).

58. See N.C. Gen. Stat. \$ 55-50(l) (1982).

59. See, e.g., Belk v. Belk's Dep't Store, 250 N.C. 99, 108 S.E.2d 131 (1959).

60. See, e.g., State ex rel. Ryan v. Cronan, 23 Nev. 437, 49 Pac. 41 (1897); State ex rel. Curtis v. McCullough, 3 Nev. 181 (1867); Beard v. Beard, 66 Or. 512, 133 P. 797 (1913); General Sherman Consol. Gold Mines, Ltd. v. Burris, 172 Wash. 142, 19 P.2d 665 (1933).

61. See, e.g., State ex rel. Curtis v. McCullough, 3 Nev. 181, 193-94 (1867); Beard v. Beard, 66 Or. 512, 517, 133 P. 797, 799 (1913); General Sherman Consol. Gold Mines, Ltd. v. Burris, 172 Wash. 142, 146, 19 P.2d 665, 666 (1933). 
Probably the most striking application of local law to an election dispute is Western Air Lines, Inc. $v$. Sobieski, a California case predating the statute discussed above. ${ }^{62}$ The controversy in Western Air Lines began when minority stockholders in a Delaware corporation with its principal place of business in California voted their shares cumulatively, as the corporation's certificate of incorporation permitted, and thereby elected two directors. ${ }^{63}$ The board of directors thereafter voted to enlarge the board by two members and to amend the corporation's certificate to eliminate cumulative voting. As the amendment required shareholder approval, proxy forms were sent to stockholders soliciting their votes in favor of the amendment abolishing cumulative voting, and a sizable majority of the shareholders voted in favor of the abolition. ${ }^{64}$ Meanwhile, California's Corporations Commissioner took the position that the amendment constituted a "sale" of Western Air Lines' securities. ${ }^{65}$ Under the California Corporation Code, prior to selling its own securities a company was required to obtain a permit from the Commissioner, who was authorized by the Code to approve the fairness of the "terms and conditions" of the sale. ${ }^{66}$ The Commissioner denied the required permit on the grounds that the elimination of cumulative voting rights was unfair to Western's stockholders, over thirty percent of whom resided in California. ${ }^{67}$ The controversy went to the Court of Appeal, which held, in essence, that the Commissioner had discretion to disregard the applicable Delaware law in favor of California's statutory mandate of cumulative voting in elections for directors. ${ }^{68}$ The decision was based in part on the fact that Western Air Lines had first become entangled with the Commissioner's authority many years earlier when it sought permission to exchange shares in the Delaware corporation for those in its California predecessor and represented that the exchange would not injure the California stockholders. ${ }^{69}$ In the court's view, however, the Commissioner's exercise of visitorial powers over a foreign corporation was justified as well by Western Air Lines' commercial presence within California. ${ }^{70}$

The cases in which courts have applied local law to impose liability on directors and officers for breaches of duties owed the corporation appear primarily to be instances in which the corporation's economic activities were situated exclusively in the forum state. As a result, a court in such a case could characterize the corporation's relationship with its state of incorporation, as did the court in State ex rel. Weede v. Iowa Southern Utilities Co.,

62. See Western Air Lines, Inc. v. Sobieski, 191 Cal. App. 2d 399, 12 Cal. Rptr. 719 (1961).

63. Id. at 401,12 Cal. Rptr. at 720.

64. Id. at 401-02, 12 Cal. Rptr. at 720-21.

65. Id. at 401-03, 12 Cal. Rptr. at 720-22.

66. See CAL. CoRp. Code $\S 25500$ (1947) (current version Cal. Corp. Code $\$ 25110$ (1977)).

67. See Western Air Lines, Inc. v. Sobieski, 191, Cal. App. 2d 399, 402-04, 12 Cal. Rptr. 719. $721-22$ (1961).

68. See id. at 410-12, 12 Cal Rptr. at 726-28.

69. Id. at 411-12, 12 Cal. Rptr. at 727 .

70. Id. at 412-13, 12 Cal. Rptr. at 727-28. 
as "more atmospheric, than real."71 In Mansfield Hardwood Lumber Co. v. Johnson, the directors and majority shareholders of a Delaware corporation were held to have breached a fiduciary relationship imposed by Louisiana law on behalf of the minority stockholders because they attempted to buy out the minority without disclosing that the corporation was to be liquidated at tremendous profit to the remaining shareholders. ${ }^{72}$ The court found that although Delaware law imposed no fiduciary obligation on the majority-a proposition with which later Delaware cases would disagree-and although the defendants' actions were consistent with the corporation's charter, the defendants had breached an obligation imposed by Louisiana law. The court held that Louisiana law applied to define the parties' relationships because the corporation's economic existence was limited to that state and its contact with Delaware was limited to the fact of its incorporation there. ${ }^{73}$

III

\section{Conflicts Among Corporation Statutes}

The outreach statutes and the case law approach epitomized by Western Air Lines, Inc. $v$. Sobieski would be merely a formal curiosity if corporation statutes were uniform in their treatment of internal affairs matters. But they are not; potentially, a corporation may be subject to conflicting (or at least different) statutory provisions from the corporation statute of its state of incorporation and from the applicable provisions of the corporation statute of the state subjecting it to regulation as a foreign corporation. The precise nature of these differences and conflicts varies considerably, at least in part because corporation statutes differ not only in detail but in basic assumptions about the appropriate regulatory force of the statute itself and about the allocation of prerogatives and risks within the corporation.

Because contemporary corporation statutes have provisions serving diverse functions, conflicts arise from the fact that each statute is itself heterogeneous and may treat a particular matter differently from the statute of any other state. Each statute contains provisions that may be classified as facilitative, suppletory, mandatory, and prohibitive. The potential for conflicts among statutes can be illustrated by examples from each of these categories.

Substantial portions of all corporation statutes are enabling or facilitative. These portions enable the organizers of the corporation to make their own agreement and embody it in the corporation's constitutional documents. Subject to later amendment through the process specified by statute, the corporation after its creation functions as the product of such private decisions or agreements. Facilitative provisions of corporation statutes also have a channeling function, in that they specify which private agreements or

71. See State ex rel. Weede v. Iowa S. Utils. Co., 231 Iowa 784, 807, 2 N.W.2d 372, 386, modified, 4 N.W.2d 869 (1942).

72. See Mansfield Hardwood Lumber Co. v. Johnson, 268 F.2d 317 (5th Cir. 1959).

73. Id. at $320-21$. 
decisions about business entities and associations will be favored with the full legal apparatus of corporate form, including the significant fact of limited liability. A simple example of a facilitative statutory provision is the "Declaration of Purposes" requirement, through which the purposes toward which the new corporation's legal powers may be used are specified by the organizing parties in the charter. ${ }^{74}$

Some statutory provisions that are enabling in that they permit enforcement of the parties' own choices, are also suppletory because they furnish a statutory standard that will govern if the parties fail to make their own specification. Thus, if the parties fail to agree on an alternative to the statutory standard, or if they prefer the statutory standard to the alternatives, their relationship on this matter is governed by the gap-filling provision in the statute. Many states' provisions concerning shareholder and director voting are an easy example of suppletory provisions that provide a statutory standard but permit some degree of variation by the parties. Under the Delaware statute, for example, all shareholder and director votes are subject to a simple majority norm, but the certificate of incorporation or bylaws may require greater majorities on all questions or those particular questions specified by the parties. ${ }^{75}$

Even at this level of statutory permissiveness, conflicts of a sort are possible between corporation statutes because the standards specified in the suppletory provisions may differ or, put differently, the various statutes embody differing presumptions about the rule that should govern in the absence of alternative provision by the parties. While a given result may require drafting out of the statutory standard in one state, it may represent the statutory norm in another state. Thus, achieving the result the parties desire obviously requires competent counseling, planning, and drafting.

An example of this kind of problem stems from the varying statutory treatments of the allocation of bylaw powers between directors and shareholders. The statute's resolution of the issue of bylaw power represents a basic decision about internal corporate governance because it embodies the residual power over most of the corporation's internal arrangements, which tend to be specified by the bylaws, such as the authorized number of directors. Statutes differ widely in their standard allocation of bylaw power. In Delaware, shareholders are granted bylaw power by statute; directors have no power to adopt, amend, or repeal bylaws unless it is granted by the certificate, provided that no such grant may reduce the shareholders' power. ${ }^{76}$ At most, directors may achieve bylaw power coequal with that of the shareholders. In California, shareholders and directors are initially vested with coequal power but the articles or bylaws may limit or restrict the board's bylaw power. ${ }^{77}$ The

74. See, e.g., MOdel Business CORP. ACT § 54(c) (1971) ("The articles of incorporation shall set forth . . . [t]he purpose or purposes for which the corporation is organized . . . .").

75. See Del. Code Ann. tit. 8, §§ 141 (b), 216 (1983).

76. See id. $\$ 109$.

77. See Cal. Corp. Code $\S 211$ (1977). 
Illinois statute grants coequal bylaw power to shareholders and directors unless some reservation to shareholders has been made in the articles. ${ }^{78}$ These statutes embody different statutory presumptions that, absent contrary provision by the parties, control the allocation of internal governance powers. Thus, the conflict at this level is in the nature of the drafting burden.

Corporation statutes also contain mandatory provisions and expressly or implicitly prohibitory provisions. These types of provisions are the most fertile ground for conflict if a corporation is subjected to the statutory directives of more than one state. Although contemporary corporation statutes contain fewer such provisions than their predecessors, ${ }^{79}$ each statute treats some topics-not always the same ones-in a mandatory or prohibitory fashion. Sometimes, a given corporation can resolve this kind of conflict simply by complying with the more restrictive of the two statutes. Conflicting dividend regulation is an example; one state may impose a more rigorous or exacting test on a proposed payment to shareholders than does the law of the other state.

Comparing the treatment of dividends in the California and Delaware statutes reveals numerous variations. In both states, it is illegal for a corporation to make a dividend payment that would leave it unable to pay its debts as they become due. ${ }^{80}$ Delaware uses the traditional "balance sheet" test which examines whether a proposed payment can be charged to any surplus account, including paid-in surplus. ${ }^{81}$ Even if the balance sheet does not show sufficient surplus, Delaware also permits the declaration of a dividend out of net profits for the current or preceding fiscal year (the "nimble dividend"). ${ }^{82}$ The test in California is more complicated and is more restrictive in some but not all instances. Under the California statute, a dividend is legal if it equals the amount of retained earnings prior to the distribution, or if after the distribution the corporation's assets equal oneand-one-quarter times its liabilities and its current assets equal current liabilities (or one-and-one-quarter times liabilities if interest expense has exceeded pretax earnings for the two prior fiscal years) ${ }^{83}$ Thus, the legality of a proposed dividend payment could vary depending upon whether Delaware's or California's statute was applied. The conflict can be resolved by comparing the statutes' assessments of the legality of a given payment, under the corporation's financial circumstances at the time, and then complying with

78. See Ill. AnN. Stat. ch. 32, § 2.25 (Smith-Hurd 1984).

79. See Folk, Some Reflections of a Corporation Law Draftsman, 42 ConN. B.J. 409 (1968); Latty, Why Are Business Corporation Laws Largely "Enabling"?, 50 CORNELL L.Q. 599 (1965). Professor Folk emphasizes the difficulty of reaching agreement on the content of a more "regulatory" corporation statute, Folk, supra, at 420 , and Dean Latty notes that while regulatory or "protective" statutes are frequently quite complex, enabling statutes have a "beautiful simplicity." Latty, supra, at 615 . In any event, the ease of foreign incorporation permits evasion of more regulatory statutes. Id. at 611 .

80. See Cal. Corp. Code $\$ 501$ (1977); of. Del. Code AnN. tit. 6, $\$ 1304$ (1975) (conveyance fraudulent as to creditors if made by person who is insolvent or is made so by conveyance).

81. See Del. Code AnN. tit. 8, \& 170(a) (1983).

82. See id.

83. See CAL. Corp. Code $\S 500$ (1977 \& Supp. 1984). 
the restrictions of the more parsimonious test. Accurate execution of this comparison, however, requires knowledge of the applicable statutory tests and facility in using them, or, more simply, larger payments to accountants and lawyers than if only one statute's regulation were evidently applicable. In any event, nothing in the Delaware statute, which is in most instances the more generous of the two, requires that dividends be declared to the full extent of their statutory legality.

Some other possible conflicts are not so readily soluble. The variation in statutory treatments of cumulative voting presents an example. In Delaware, ${ }^{84}$ and under the Model Business Corporation Act, ${ }^{85}$ cumulative voting is permitted but not mandated. The statutory norm in Delaware is straight voting unless the certificate of incorporation provides for cumulative voting. ${ }^{86}$ In California ${ }^{87}$ (and about twenty other states), ${ }^{88}$ cumulative voting is mandatory and may not be "written out" by the parties in a certificate provision specifying the use of straight voting. ${ }^{89}$ Thus, if one supposes that a Delaware corporation without a certificate provision electing cumulative voting is subject to California's statutory mandate through section 2115 , it is not wholly satisfactory to say that the corporation can resolve the conflict by complying with the "more restrictive" statutory regimen. For which is more restrictive?

Whether shareholders have the right to vote cumulatively, so that holders of sizable minority blocks may elect a director, is not a choice that can be analyzed in terms of relative restrictiveness. Nor can it be seen as a pro- or anti-stockholder, pro- or anti-management choice. Cumulative voting affects the allocation of voting power as between majority stockholders and sizable but noncontrolling minority interests. Indeed, if the Delaware corporation's choice not to elect cumulative voting was a considered decision, it represents a choice to further the interest of one group of stockholders (the majority) over the others (large minority blocks). If this choice is the product of a bargain between the company's stockholders about the allocation of voting power amongst themselves, then that bargain is abrogated when the corporation is compelled to comply with the mandatory cumulative voting provisions in the California statute. The conflict, then, is between the voting arrangements made by private parties through an agreement permitted by one statute and another statute's inconsistent mandate. To be sure, present stockholders of the corporation may argue that they were not parties to the original agreement to use straight voting and thus are not bound by it. In addition, original stockholders may argue that they no longer agree with the majority and thus should be allowed to vote cumulatively to place their champion on the board. But the risk of enforced acquiescence in prior

84. See Del. Code ANn. tit. 8, §§ 212, 214 (1983).

85. See Model Business Corp. ACt $\S 33$ (1971).

86. See Del. Code ANn. tit. 8, § 212 (1983).

87. See Cal. Corp. Code $\& 708(a)$, (b), (c) (1977 \& Supp. 1984).

88. See Model Business Corp. Act $\S 33$ \ 4 comment 93.03 (Supp. 1977).

89. See Cal. Corp. Code $\S 204($ a)(5) (1977 \& Supp. 1984). 
choices made by others-or for that matter by oneself-is a standard contractual risk of buying or owning less than a controlling share of a corporation. Is the risk of not being able to vote cumulatively any different?

In any event, even worse conflicts over cumulative voting are conceivable. At least two states, Massachusetts ${ }^{90}$ and New Hampshire, ${ }^{91}$ appear not to authorize the practice. A rationale behind this position, which seems at least as compelling as the rationales supporting statutory compulsion of cumulative voting, is that directors are better able to fulfill their fiduciary obligations to the corporation and the shareholding body as a whole if they are not blatantly identifiable with particular constituencies among the stockholders. Indeed, the board may be better able to function as a cohesive body-whether to manage or to superintend the management efforts of others-if its members do not include the representatives of minority factions of stockholders. These statutory goals cannot be dismissed lightly as ill-conceived or unduly permissive, but California's assertion of internal affairs power through section 2115 purports to require that subject corporations disregard such policies of their state of incorporation.

Another serious conflict in internal affairs provisions arises from the variations in treatment of removal of directors from office prior to the expiration of their terms. In some states, a court could likely remove directors from office, ${ }^{92}$ and probably in most states a majority of the stockholders could do so as well, ${ }^{93}$ upon a sufficient showing of cause for removal. States differ, however, on the removal of directors without cause, that is, without any showing that directors have been faithless as fiduciaries or especially inept as managers.

Delaware and California, once again, differ somewhat in their treatment of removal without cause. Although directors may be removed for cause in both states, ${ }^{94}$ only in California may directors always be removed without cause by a majority vote of the stockholders, subject to the protection of stockholders' cumulative voting rights. ${ }^{95}$ A director cannot be removed without cause if the number of shares cast against his removal would be sufficient to elect him if voted cumulatively in an election for the entire number of directors elected at

90. See Mass. Gen. Laws Ann. ch. 156, $\$ 32$ (West 1979).

91. See N.H. Rev. Stat. Ann. ch. 294, $\$ 85$ (1978). The relevant language of the New Hampshire statute provides that "[u]nless the articles of agreement on the votes authorizing the issue of the stock shall otherwise provide, stockholders shall have one vote for each share of stock owned by them." Although the New Hampshire position has been equated to that of Massachusetts, see Model Business Corp. ACT $\S 33$ I 4 comment $\$ 3.04$ (1971), the statutory language at least suggests the possibility that cumulative voting might be authorized in the articles. Nothing in the statute refers to the mechanisms of cumulative voting, however, making it likely that $\S 85$ refers to the creation of shares with unequal voting power rather than a general cumulative voting scheme. As New Hampshire does not authorize removal of directors without cause, the statute's failure to refer to the preservation of cumulative voting rights in the removal context is of less moment.

92. See Model Business Corp. ACT $\$ 39$ comment 94.03 (1971).

93. See W. Cary \& M. Eisenberg, Cases and Materials on Corporations 142 (5th ed. 1980).

94. Compare CAL. CoRP. CoDE $\S 304$ (1977) (authorizing suit brought by at least ten percent of the stockholders to seek director's removal for cause by Superior Court), with DEL. Code ANN. tit. 8, $\S 141(\mathrm{k})$ (majority of stockholders may remove director for cause).

95. See Cal. Corp. Code $\S 303$ (1977). 
the same time as the director facing removal. ${ }^{96}$ In effect, if the director still has the support of the block of shares that originally elected him, he cannot be removed. Further, like the stockholders' right to vote cumulatively, the right to remove directors by majority vote cannot be modified or altered through certificate provisions. ${ }^{97}$ In contrast, under the Delaware statute, if there is no certificate provision granting the right to remove without cause, shareholders have the right to remove directors without cause only if the board is not classified, in other words, only if all directors' terms expire at the same time. ${ }^{98}$ Thus, if the board is classified, and nothing in the certificate permits removal without cause, directors in a Delaware corporation cannot be removed without a showing of cause. Obviously, the conflict between the California and Delaware provisions is substantial if section 2115 mandates the application of California's removal rights to a Delaware corporation.

Two further complications may arise. First, while the California statute, by requiring that all directors be elected annually, ${ }^{99}$ appears to prohibit a Delaware corporation subject to section 2115 from staggering the terms of its directors, it allows the division of shares into classes and the election of a designated number of directors by those classes. ${ }^{100}$ Second, classified shares may reduce the force of shareholders' right to vote cumulatively and to remove directors, by reducing the numbers of directors for whom a particular stockholder is entitled to vote and whom he may seek to remove. ${ }^{101}$ If parties are aware of this possibility and use it carefully, they may vitiate the force of California's statutory mandates by limiting the proportion of the corporation's shares to which any given stockholder's cumulative voting and removal rights are applicable. ${ }^{102}$ This obvious route through which the cagey-or well advised-corporation may evade California's mandate calls into question the strength of the state's assertion of its interest in mandating cumulative voting for poorly advised or merely docile corporate subjects. ${ }^{103}$

These complications aside, the question of removal without cause, like that of cumulative voting, does not have a right or wrong answer. If directors are easily removed without cause, as in California, and the removal rights of a majority of the stockholders cannot be foresworn through charter provisions, obviously the residual power of a majority of the shares is strengthened as

96. See id. $\S 303(\mathrm{a})(1)$.

97. See id. § 204(a)(5) (1977 \& Supp. 1984).

98. See Del. Code AnN. tit. $8, \S 141(\mathrm{k})$ (i) (1983).

99. See Cal. Corp. Code $\$ 301$ (a) (1977).

100. See id. $\$ \S 202(\mathrm{e})(3), 301(\mathrm{a}), 400(\mathrm{a})$.

101. See Halloran \& Hammer, Section 2115 of the New California General Corporation Law-The Application of California Corporation Law to Foreign Corporations, 23 UCLA L. Rev. 1282, 1298-99 (1976).

102. See id. at 1298-1300.

103. See Latty, supra note 14 , at 160 . Dean Latty argues that "there is not much point in insisting on application of local law" to a foreign corporation if a domestic corporation could legally circumvent the statutory requirement because such requirements do not represent strong policies of the state. See id. But see Kaplan, supra note 37, at 474 (rejecting test equating public policy with nonevasory statutory requirements because most such features of corporation statutes can effectively be circumvented). This criticism has force, however, only if one begins with the assumption that it is desirable that local law be applicable to the internal affairs of foreign corporations. 
against that of the directors. This may appear wise when a majority or controlling block is sold so that holdover directors may be readily removed or persuaded to resign by the new majority stockholder. If removal without cause is less readily available, as in Delaware, directors on balance are more insulated from the vicissitudes of majority shareholder favor and fancy, and are more likely to concern themselves with the interests not just of the majority, but of all the shares. A statutory bias or preference against removal without cause is not obviously wrongheaded or unfair, and the parties' choice not to include removal without cause language in the constitutive documents of a Delaware corporation is again the product of the agreement among majority stockholders, nonmajority stockholders, and directors about their respective prerogatives.

States other than Delaware have staked out positions on the removal of directors that are in irreducible conflict with the California statute. Some states, including Kansas and New Hampshire, do not permit removal without cause, shifting Delaware's statutory bias against removal into a prohibition. ${ }^{104}$ A corporation incorporated in a state that does not provide for removal without cause (which one can assume is not the result of an inadvertent omission by the legislature) cannot consistently comply as well with the California removal provision made applicable through section 2115.

A final example of irreducible conflict is found between the Delaware and California indemnification provisions. Suppose that a corporation incorporated in Delaware is also subject to California's regulation under section 2115, and that the question in issue is whether the corporation is obliged to indemnify a corporate officer for expenses incurred in litigation related to the person's corporate office. Section 121(b) of the Delaware statute provides that all Delaware corporations shall be "governed by the provisions and subject to the restrictions and liabilities" in the statute. ${ }^{105}$ Further, the Delaware statute mandates indemnification to the extent that the defendant has been successful in defending against the litigation "on the merits or otherwise."106 California requires indemnification only to the extent that the defendant has succeeded "on the merits."'107 Conflict between these indemnification provisions will occur if the particular defendant has "succeeded" in some fashion other than "on the merits," perhaps by pleading the statute of limitations or by obtaining the dismissal of a criminal action after a successful challenge to the legality of a search. The corporation in this example cannot comply with the inconsistent mandates of both states. The practical significance of this conflict, however, may be lessened because both

104. Other jurisdictions that do not statutorily authorize removal without cause are Alaska, Louisiana, South Dakota, Vermont, and the District of Columbia.

Only since July 1, 1984 has Illinois permitted removal without cause. See Ill. ANN. STat. ch. 32, $\S 8.35$ (Smith-Hurd 1984). In Illinois, like California, share classification restricts the shareholders' right to remove directors elected by their particular class of shares. Id. $\$ 8.35(3)$.

105. See Del. Code AnN. tit. 8, § 121 (b) (1983).

106. Id. $\S 145(\mathrm{c})$.

107. See Cal. Corp. Code $\$ 317$ (d) (1977 \& Supp. 1984). 
the California and Delaware statutes permit corporations to purchase insurance against even those liabilities of their agents that the corporation could not directly indemnify. ${ }^{108}$

\section{IV}

\section{Statutory Retaliation}

The conflicts among state statutory provisions described above are in large part the product of two kinds of differences in legislative goals expressed in the corporation statutes. First, the statutes differ in their assumptions about the appropriate norms of internal corporate governance to be imposed by a statutory standard. For example, states that prohibit removal of directors without cause (like Kansas) or set the statutory presumption to make removal more rather than less difficult (like Delaware) effectively strengthen the hand of directors vis-à-vis that of majority stockholders. States like California that mandate that directors be removable without cause or that, without granting a majority of the shares an irrevocable right of removal, set a statutory presumption of easy removal, effectively strengthen the position of the majority stockholder vis-à-vis that of the directors.

Less evident, but nonetheless important, are differing conceptions of the function of the corporation statute and its regulatory potential. The statutory tradition epitomized by Delaware tends on balance, as the examples above illustrate, to minimize the role of the state in prescribing specific internal governance arrangements in preference for validating private parties' agreements. The standards furnished in the statute to deal with questions like voting arrangements can be replaced by the parties' own choice; Delaware's statutory presumption in favor of straight voting may be supplanted by the parties' election of cumulative voting. This deference to private agreements represents, in short, a highly contractual view of corporation law: subject to compliance with fairly minimal statutory requirements, the parties "make their own law" as in any private contract and are privileged by the state to operate in corporate form with limited liability.

Notwithstanding the success of the contractualized Delaware model in attracting incorporations to Delaware and in the statute's appeal as a model for other states, some jurisdictions have long pursued a somewhat different conception of the proper function of corporation statutes. Though limited in number, these jurisdictions support what may well be viewed as a "counterculture" of corporation law, counter, that is, to the dominant contractualized approach. These states' statutes tend, quite simply, to be more unequivocally mandatory or prohibitory on a number of matters and to use state prescription rather than private agreement as the mechanism for fleshing out the corporation's internal structure, thereby establishing the respective powers and rights of its constituents. Behind these statutes lies,

108. See id. $\S 317(\mathrm{i})$; Del. Code AnN. tit. $8, \S 145(\mathrm{~g})(1983)$. The popularity of such insurance is greater among large corporations. See W. CARY \& M. EISEnbERG, supra note 93, at 969-70. 
perhaps, a relatively optimistic view of the capacity of state prescription to protect effectively the corporation's creditors and noncontrolling stockholders and maybe even the public at large. ${ }^{109}$

Indeed, some statutes within this countercultural tradition are so structured as to have limited appeal to organizers of a corporate enterprise, unless those organizers contemplate a wholly local operation or know from the start that they wish to strengthen the prerogatives of minority shareowners in the enterprise. Perhaps the most extreme example of a statute in this tradition is that of North Carolina. Like the California statute, it mandates cumulative voting, ${ }^{10}$ although the stockholders' right to remove directors without cause by majority vote may be abrogated through a charter provision or shareholder bylaw. ${ }^{11}$ Unlike the California statute, however, the North Carolina act grants the holders of at least twenty percent of the shares in closely-held corporations the right to compel the payment in dividends of one-third of the corporation's earnings. ${ }^{112}$ Overall, in the judgment of the leading authority on the statute, "Practitioners retained by the promoters or top management of . . . [a publicly-held] company may conclude that the protective features of the North Carolina statute, although not as strict as they originally were, still cause too much risk and uncertainty." 113 To be sure, the risk of enacting a countercultural corporation statute is that few will elect to incorporate under it.

The outreach provisions in corporate statutes, along with cases like Western Air Lines, Inc. $v$. Sobieski, 14 are the choice of law counterpart to this counterculture in corporation statutes, and as such, they aggrandize the effect of the remainder of the statute by making it applicable at least in part to enterprises incorporated elsewhere. Supporters of statutory outreach justify its applicability to corporations that are truly pseudo-foreign, as well as to corporations that are less than entirely pseudo-foreign, by arguing that the appeal of statutes like Delaware's is in some respect illegitimate, or at any rate readily ignored to give preference to another state's regulatory choice. ${ }^{115}$ Statutory outreach provisions are thus a retaliatory weapon: they are designed to reduce the appeal of Delaware incorporation by creating the possibility that another state's corporation law will supplant the law of Delaware. ${ }^{116}$

109. For an argument that corporation statutes ought to be used to enable the state to control corporations' economic power and affronts to the environment, see Comment, Law For Sale: A Study of the Delaware Corporation Law of 1967, 117 U. PA. L. REv. 861, 897-98 (1969). This position, however, does not establish that corporation statutes are superior to other vehicles for regulating such matters.

110. See N.C. Gen. Stat. § 55-67(c) (1982).

111. See id. $\$ 55-27(f)$.

112. See id. $\$ 55-50(1)$.

113. See R. Robinson, North Carolina Corporation law and Practice \$ 2-3, at 16 (3d ed. 1983); see also Hazen, Book Review, 61 N.C.L. Rev. 1256, 1259 (1983).

114. 191 Cal. App. 2d 399, 12 Cal. Rptr. 719 (1961).

115. See, e.g., Oldham, supra note 39 , at $99-104$.

116. See, e.g., Note, The Pseudo-Foreign Corporation in Califormia, 28 Hastincs L. J. 119, 121 (1976) (section 2115 as a "means to combat the influence of the permissive states over corporate law"); 
The defense of statutory retaliation is vulnerable on a number of counts, including its empirical presuppositions and the negative implications regarding state power drawn from the commerce clause of the Constitution. An image that arises frequently in the anti-Delaware literature is that of bad law driving out good, described as the "Gresham's Law" effect. ${ }^{117}$ Delaware law is the "bad" in this construct, driving out the good of North Carolina and California, among others. What makes Delaware "bad" to these observers is the contractual tradition described above; the contractual approach is said to make the Delaware statute unduly permissive and solicitous of management's interests at the expense of stockholders, especially minority stockholders. 118

Management-or controlling stockholders-chooses the site of incorporation, and by choosing Delaware can systematically advance its interests over those of minority stockholders. The obvious empirical question is whether the ability freely to choose the Delaware statutory regimen produces bad effects. If not, the argument for suppressing the choice of Delaware through outreach statutes is severely weakened. Investigations pertinent to this question do not demonstrate that the contractual norm in Delaware's law has malign consequences.

In order to evaluate the thesis that Delaware incorporation permits corporate managers to exploit shareholders, one study examined the impact of reincorporation on the stock market price of corporations that changed their state of incorporation to Delaware. The study posited that the market price of corporations electing to reincorporate in Delaware should plummet if investors view Delaware incorporation as a serious peril to their interests. The data showed no negative market reaction after Delaware reincorporation, however. ${ }^{119}$ To be sure, the significance of this finding is limited because movements in stock prices necessarily reflect many factors and it is difficult to isolate the influence of the state of incorporation. Further, the study included only industrial corporations listed on stock exchanges; the consequences of Delaware incorporation for other kinds of corporations were not studied. Nonetheless, one need not possess a Panglossian optimism about the significance of stock price movements to recognize that the fact of Delaware

Comment, Choice of Corporation Domicile: California or Delaware?, 13 U.S.F. L. REv 103, 104 (1978) (California's statute "threatened Delaware's unchallenged status as the foremost state for incorporation"). But cf. Jennings, The Role of the States in Corporate Regulation and Investor Protection, LAw \& Contemp. Probs., Spring 1958, at 193, 207 (advocating protection of state's interest in compliance with provisions of corporation statutes through regulation administered under aegis of state securities act).

117. Sir Thomas Gresham (1519-1579) served as a royal factor, that is, a representative of the crown to the Antwerp money market. The aphorism known as Gresham's Law, "bad money drives out good," was not devised by Gresham himself but was instead attributed to him by Henry D. McLeod, a nineteenth century economist. At most, Gresham stated in his writings that Henry VIII's debasement of the currency caused the exchange rate to fall, with the result that the export of fine coins from the realm became profitable and overvalued base money took its place in circulating currency. See R. deRoover, Gresham on Foreign Exchange (1949).

118. See, e.g., Cary, Federalism and Corporate Law: Reflections Upon Delaware, 83 Yale L.J. 663 (1974).

119. See Dodd \& Leftwich, The Market for Corporate Charters: "Unhealthy Competition" versus Federal Regulation, 53 J. Bus. 259 (1980). 
incorporation appears not to impede investment in Delaware corporations. Perhaps potential investors are more interested in other aspects of a particular corporation, since the profitability of investing in corporations is, on average, much more heavily influenced by factors such as the quality of the enterprise's management and product. In any event, no empirical case has been rigorously mounted for the attack on the contractualized nature of Delaware corporate law. ${ }^{120}$

Another difficulty with the defense of statutory retaliation stems from the nature of the topics dealt with by state corporation statutes, even the relatively restrictive codes. In the United States, the task of defining standards of fiduciary behavior has been left to the courts; legislatures seem to enter this arena primarily to relax, through revisions to the corporation statute, rules established by the courts to regulate the actions of officers, directors, and controlling stockholders. ${ }^{121}$ Congress has supplanted the fiduciary restraints for those corporations and transactions subject to the federal securities laws. State corporation statutes, in contrast, are silent on a number of significant problems arising out of transactions that appear to call into question the fiduciaries' loyalty to the corporation. For example, state statutes do not regulate the ability of fiduciaries to use corporate assets to maintain their control of the corporation or to cause the corporation to repurchase its stock at a premium price from selected (and fortunate) stockholders. ${ }^{122}$ Indeed, although both New York and California have statutory channels enablingwith limitations - the validation of transactions between the corporation and certain fiduciaries, ${ }^{123}$ they are not made applicable to foreign corporations through the outreach provisions of either statute. The difficulty, in short, is that the outreach statutes do not address the major offenses of the day against stockholders' interests and instead focus on matters of relatively less moment.

120. See Kitch, A Federal Vision of the Securities Laws, 70 VA. L. REv. 857, 872-83 (1984).

121. See Latty, supra note 79 , at 606 .

122. See id. at 608. The practice of selected stock repurchases continues to be a problem, now characterized in the take-over context as "green mail." Stock repurchases at premium prices to buy out persons who might take over the corporation through a hostile tender offer produced public outrage in 1984, along with proposed federal legislation. See H.R. 5693, 98th Cong., 2d Sess. (1984) (prohibiting repurchase at above market price from person owning more than three percent of class of securities to be purchased, unless a majority of issuer's voting securities approves the repurchase, or unless an equal offer is made to all holders of the class of securities). In 1985, the California Court of Appeal upheld the trial court's issuance of a preliminary injunction that effectively imposed a constructive trust on the proceeds of a green mail transaction; the selling stockholder had abandoned derivative litigation it brought on behalf of the corporation when it sold its stock back to the company, thereby, in the Court of Appeal's view, breaching a fiduciary relationship voluntarily undertaken on behalf of the other stockholders. See Heckmann v. Ahmanson, 168 Cal. App. 3d 119, 214 Cal. Rptr. 177 (1985).

123. See Cal. Corp. Code $\S 310$ (1977); N.Y. Bus. Corp. Law $\S 713$ (McKinney 1963 \& Supp. 1984). 


\section{Constitutional Considerations}

\section{A. The Commerce Clause}

Statutory retaliation, as represented by the outreach statutes, is also problematic in light of the limits on state power implicit in the commerce clause. The Supreme Court has long interpreted that clause, providing that "Congress shall have Power . . . [t]o regulate Commerce . . . among the several States," 124 to mean that states may not directly regulate interstate commerce but may regulate it indirectly unless the burden imposed on interstate commerce exceeds the "putative" local benefits of such regulations. ${ }^{125}$

The Supreme Court most recently interpreted the commerce clause as it pertains to state corporate regulation in Edgar $v$. MITE Corp. ${ }^{126}$ The statute challenged in Edgar, the Illinois Business Take-Over Act, ${ }^{127}$ required that any tender offer for a target company within the Act's purview be preceded by twenty days' advance notice to the Illinois Secretary of State and to the target's management. ${ }^{128}$ During the twenty-day period, the Secretary was empowered to call a hearing to adjudicate the equity of the offer and the adequacy of the offeror's disclosure. ${ }^{129}$ While the offeror was prohibited from communicating its offer to target shareholders, target management was free to contact them concerning the offer. ${ }^{130}$ The statute enabled the Illinois Secretary of State to block an offer from proceeding anywhere in the nation upon a finding that the offer was inequitable or fraudulent, or that the offeror had not complied with the statute's disclosure requirements, and any offeror who proceeded without compliance was subjected to civil and criminal penalties. ${ }^{131}$ The statute applied to offers for target companies if Illinois shareholders owned ten percent of the class of securities subject to the offer, or if any two of three conditions were met: the target had its principal executive office in Illinois, was incorporated in Illinois, or had at least ten percent of its capital and paid-in surplus represented within the state. ${ }^{132}$ The Court held that the burden on interstate commerce was unconstitutionally excessive in relation to the local interests served by the statute, ${ }^{133}$ and four Justices agreed that the statute improperly imposed direct regulation on interstate tender offers from which interstate transactions would follow. ${ }^{134}$

124. U.S. Const. art. I, $\S 8$, cl. 3 .

125. See Pike v. Bruce Church, Inc., 397 U.S. 137, 142 (1970).

126. 457 U.S. 624 (1982).

127. See Pub. Act No. 80-1421, 1978 Ill. Laws 1581 (codified at Ill. Rev. Stat. ch. 121.

I 137.51-.70 (1979) (repealed 1983)).

128. See Edgar, 457 U.S. at 627.

129. Id.

130. Id. at 634-35.

131. Id. at 627 .

132. Id.

133. Id. at $640,643-46$.

134. Id. at 641-43 (opinion of White, J.). 
Three justices would also have held that the statute substantially frustrated the objectives of the Williams Act and was therefore preempted by it. ${ }^{135}$

Analysis of the statute's direct restraint on interstate commerce turned on the fact that the statute on its face purported to apply to the offeror's communication of its offer to shareholders situated outside Illinois and that the offer, if accepted, would thus result in transactions in interstate commerce. If Illinois could impose such a statute, so could other states, and the interstate commerce produced by tender offers would be "thoroughly stifled."136

The Edgar holding, however, was based on the Court's analysis of the Illinois statute as an indirect regulation of interstate commerce. Illinois regulation would burden interstate commerce, the Court observed, because permitting the Secretary of State to block a nationwide tender offer would deprive stockholders, among others, of the benefits stemming from the offer. ${ }^{137}$ In the balance, Illinois had argued that its statute furthered the local interests of protecting resident Illinois investors and regulating the internal affairs of Illinois corporations. ${ }^{138}$ The Court dismissed these asserted local interests; the statute's applicability to non-Illinois corporations and corporations without Illinois shareholders belied the state's asserted purpose, ${ }^{139}$ while the statute's provisions to protect shareholders substantially duplicated those of the Williams Act. ${ }^{140}$ Finally, insofar as the statute applied to corporations not incorporated in Illinois and with their principal places of business in other states, the Court observed that "Illinois has no interest in regulating the internal affairs of foreign corporations." 141

Much in Edgar appears to be pertinent to the choice of law statutes discussed above. Preliminarily, however, it is useful to isolate one factor present in Edgar but not in the corporate choice of law problem, namely, the substantial federal presence in tender offer regulation created by Congress through the Williams Act in 1968. To what extent does the presence of relatively comprehensive federal regulation limit Edgar's significance as a

135. Id. at 630-40 (opinion of White, J.).

136. Id. at 642 .

137. Id at 643. Part of Justice White's reasoning has been trenchantly criticized by Professor Richard Buxbaum, who rightly observes that the opinion unnecessarily conjoins the commerce clause to "an institutionally and theoretically unsupportable version of the efficient capital market hypothesis." Sep Buxbaum, Corporate Ligitimacy, Economic Theory and Legal Doctrine, 45 OHIO ST. L.J. 515,534 (1984). One passage in Justice White's opinion, for example, asserts that the mechanism of hostile tender offers affords incumbent corporate management incentives to perform well and to reallocate corporate assets to their highest valued use. See 401 U.S. at 643-44. As Professor Buxbaum observes, another hypothesis supported by available evidence is that many hostile takeover bids are simply redistributive events that shift wealth from one group of stockholders to another but are unrelated to efficiency considerations. See Buxbaum, supra, at 533-34.

138. Edgar, 457 U.S. at 644

139. Id. at $645-46$.

140. Id. at $644-45$.

141. Id. at 645-46. Althoagh critical of the Court's commerce clause analysis in Edgar, Professor Buxbaum has conceded nonetheless that a state could not constitutionally regulate a tender offer simply because one shareholder resides in the state. See Buxbaum, Federalism and Company Law, 82 Mich. I.. REV. $1163,1173-74$ (1984). 
reading of the commerce clause? The existence of the Williams Act enters the Court's analysis only insofar as it affects the local benefit derived from Illinois regulation; beyond that, Edgar may be read to postulate that state regulation of tender offers, at least in the grand style of Illinois, would be unconstitutional even in the absence of any federal regulation.

Moreover, the Court prior to Edgar has held unconstitutional on commerce clause grounds state statutes that, in the absence of federal regulation, burdened interstate commerce by placing interstate firms under inconsistent regulatory mandates. For example, in Bibb v. Navajo Freight Lines, Inc., ${ }^{142}$ the Court struck down an Illinois statute requiring the use of contoured rear fender mudflaps on trucks and trailers operating within that state because forty-five states permitted the use of conventional or "straight" mudflaps, and Arkansas (adjacent to Illinois) required straight mudflaps. Further, switching mudflaps on trucks entering or leaving Illinois would impose a significant delay of at least two hours. The Court held that even if the mudflap design mandated by Illinois was in isolation a reasonable exercise of the state's police power, its idiosyncratic nature imposed a burden on interstate commerce by subjecting carriers to inconsistent regulatory obligations that were constitutionally impermissible. ${ }^{143} B i b b$, read against Edgar, means that the absence of federal regulatory involvement in itself does not limit the applicability of the commerce clause to state regulations and that the significant question is whether those regulations, inconsistent with each other or not, unduly burden interstate commerce.

Assessing the validity of these "outreach" choice of law doctrines under the commerce clause thus requires that a number of questions be addressed: (1) to what extent does the application of local corporate law to internal affairs questions in foreign corporations involve the regulation of interstate commerce; (2) if interstate commerce is thereby regulated, is it regulated directly or only incidentally; (3) if the regulation is incidental, does it burden interstate commerce; (4) if interstate commerce is burdened by the regulation, is the burden disproportionate to any legitimate local interests furthered by the regulation? Although answering some of these questions is far from easy, the analytic process demonstrates considerable constitutional vulnerability in the "outreach" approach.

It is clear from Edgar that to be invalid under the commerce clause a statute need not impose regulation directly on interstate transactions in goods and services. The tender offers regulated by the Illinois statute in that case were one step removed from transactions in securities that would only occur once the offer was accepted by shareholders. Thus, the statute's propensity to affect interstate commerce is the relevant criterion.

A number of such effects seem likely under the "outreach" schemes. First, the applicability of the California and New York provisions turns on factors

142. 359 U.S. 520 (1959).

143. Id. at 529-30. 
that probably implicate interstate commerce. Whether a foreign corporation does business or has assets or an executive office situated within a state are factors within the corporation's control. If the applicability of particular internal affairs rules turns on these matters, a corporation may choose to do less business within a state or locate its offices and principal assets elsewhere. These self-protective decisions a fortion involve transactions in interstate commerce. Second, some of the internal affairs provisions of corporation statutes made applicable to foreign corporations through the "outreach" effect themselves involve transactions in interstate commerce. Under section 2115 of the California Corporations Code, for example, the statute's provisions regulating dividends are made applicable to foreign corporations, and surely the payment of a dividend by a foreign corporation from California assets to a non-California stockholder is a transaction in interstate commerce.

Nonetheless, the one California case to focus on this particular question arrived at a different answer. In Valtz v. Penta Investment Corp., ${ }^{144}$ the Court of Appeal dismissed appellant corporation's challenge to the constitutionality of section 1600 of the Corporations Code, which required that a foreign corporation with executive offices situated in California comply with the Corporations Code's provision on shareholders' inspection rights. The court dismissed appellant's commerce clause argument with the observation that section 1600 did not affect interstate commerce because the corporation had been unable to show any relationship between its ability to do business in more than one state and its duty to provide a shareholder list. ${ }^{145}$ But the relevant question under the Supreme Court precedents appears to be whether the regulation may have some impact on interstate commerce and not simply on the business locations or interstate sales of products by the firm. The implication from section 1600 , that its mandate can be avoided if the company relocated its executive offices outside California, would seemingly affect interstate commerce, at least commerce in executive offices and their accouterments! In any event, it is much more difficult to argue that the full range of California regulation made applicable to foreign corporations through section 2115 would not have some effect on interstate commerce, most notably so in the case of dividends, merger regulation, and shareholders' appraisal rights.

Some of the same aspects of these outreach provisions that can be seen to "affect" interstate commerce appear also to amount to the direct regulation of interstate commerce and, indeed, of transactions taking place wholly outside the state's boundaries. Section 2115, for example, purports to make California dividend regulation applicable to a foreign corporation's payment of dividends from non-California bank accounts to non-California sharcholders. Such a result may exemplify the direct regulation of Iransactions in interstate commerce toward which the Supreme Court's interpretation of the commerce clause is especially hostile.

144. 139 (al. App. 3d 803, 188 Cal. Rptr. 922 (1983).

145. Id. at 808-09, $188 \mathrm{Cal}$. Rptr, at 925-26. 
The question of burden on interstate commerce appears not to be completely independent of the question of effect on it. Thus, to the extent that a statute discourages interstate transactions, it both affects and burdens commerce. Moreover, the Supreme Court's interpretations suggest some additional meaning for the burden criterion. As noted earlier, the Court in $B i b b$ declared that state rules imperimissibly burden interstate commerce if they impose mutually inconsistent regulatory burdens on the parties subject to them, or if the costs of complying with both regulatory obligations are substantial. Curiously, the most recent California case to consider the constitutionality of section 2115 gave short shrift to these questions. In Wilson v. Louisiana-Pacific Resources, Inc., ${ }^{146}$ the Court of Appeal held that section 2115 was not unconstitutional in its application of California's Code provision mandating cumulative voting to a Utah corporation that had not elected cumulative voting in preference to the straight voting structure contained in the Utah corporation statute. The court observed that the criteria specified in section 2115 minimized the "potential for conflict and resulting uncertainty," 147 and that even "[i]f California's statute were replicated in all states, no conflict would result" 148 because section 2115 is not applicable unless a majority of a corporation's business is done in the state.

One difficulty with this line of reasoning is that it ignores entirely the conflict between the California statute and the Utah statute under which the company was incorporated. Utah's statute enables the parties to choose the applicable voting rule. ${ }^{149}$ It further provides that corporations created under it are "subject to the provisions of this act," 150 including the provision that $[u]$ nless the articles of incorporation otherwise provide, at each election for directors every shareholder entitled to vote . . . shall have the right to vote . . . the number of shares owned by him for as many persons as there are directors to be elected...."151 True, the conflict in Wilson is not as melodramatic as a conflict between California's statute and one prohibiting cumulative voting, but that does not mean there is no conflict, or that it should be ignored by the court. Although it is possible under the Utah statute for the corporation's charter to be amended by the shareholders and the

146. 138 Cal. App. 3d 216, 187 Cal. Rptr. 852 (1982).

147. Id. at 226-27, 187 Cal. Rptr. at 860 .

148. Id. at 227, 187 Cal. Rptr. at 860 . The court observed in Wilson that no serious impact on corporations resulted from the New York provisions applicable to foreign corporations. Id. at 227 n.7, 187 Cal. Rptr at 860 n.7. The New York experience is somewhat beside the point in light of the substantial differences between New York's and California's "outreach" provisions. See supra text accompanying notes 17-32.

149. See Utah Code Ann. $\$ 16-10-31$ (1973).

150. Id. \& 16-10-2(a) (Supp. 1983).

151. Id. \& 16-10-31. The court's observation in Wilson that "Utah . . has no interests which are offended by cumulative voting," 138 Cal. App. 3d at 223, 187 Cal. Rptr. at 857, ignores Utah's interest in the enforcement of the statutory provisions quoted in the text. Perhaps the court assumed in Wilson that only states mandating or prohibiting cumulative voting articulate a relevant state interest. If so, that assumption reflects a fairly narrow conception of the nature of corporation statutes, which is inconsistent with some of the academic writing on this topic. See, e.g., Kaplan, supra note 37, at 47475. 
directors, ${ }^{152}$ that mechanical fact does not establish California's right to coerce such an amendment.

In Valtz v. Penta Investment Corp., there was an even more palpable conflict between state statutes. Under section 1600(a) of the California Corporations Code, a shareholder holding at least five percent of a corporation's voting shares has an absolute right to obtain a shareholder list for the corporation, regardless of his reasons for wanting the list. ${ }^{153}$ In contrast, under title 8 , section 220(b) of the Delaware Code, while any shareholder regardless of the size of his holdings may demand to inspect (and presumably copy) the shareholder list, only those shareholders with a "proper purpose" have the right to inspect. ${ }^{154}$ "Proper purpose" is defined by the Delaware statute to be "a purpose reasonably related to such person's interest as a stockholder,"155 and would not authorize inspection to obtain a list to sell or solely to enable the stockholder to compete in business with the corporation. ${ }^{156}$

The Valtz court ignored the significance of the conflict between the California and Delaware provisions, observing that the "internal affairs" doctrine was inapplicable because the inspection rights granted by section 1600 of the California Code were rights incidental to the ownership of stock and affected "the relationship between corporation and shareholder," thereby subjecting those rights to regulation by the state where the corporation does business. ${ }^{157}$ To be sure, "doing business" is not the test posed by section 1600 (d) for its applicability to foreign corporations, ${ }^{158}$ but in any case this conception of the nature of the matter being regulated potentially applies to all internal affairs questions as well, for they all surely concern at some point the relationship between a corporation and its stockholders. The more important point is that through section 1600, California purports to regulate the inspection rights even of non-California stockholders and ignores the initial and continuing expectations of parties who chose to incorporate in Delaware, which more carefully regulates the exercise of inspection rights.

The indifference to the expectations of parties who chose to incorporate in Delaware reflected in sections 1600 and 2115 of the California Corporations Code is especially troubling given facts like those in Valtz. In that case, the two stockholders seeking to exercise inspection rights were among the five founding stockholders of the corporation, which was in the business of manufacturing, wholesaling, and retailing prescription eyewear. The plaintiffs subsequently established and operated a competing chain of retail eyeglass stores and were discharged from their corporate offices. After demanding

152. See Utah Code AnN. $\S 16-10-55$ (1973).

153. See Cal. Corp. Code $\S 1600$ (a) (West 1977 \& Supp. 1984).

154. See Del. Code Ann. tit. 8, § 220(b) (1983).

155. Id.

156. See E. Folk, The Delaware General Corporation law 253 (1972).

157. See Valtz, 139 Cal. App. 3d at 807, 188 Cal. Rptr. at 924.

158. See CaL. Corp. CoDE $\S 1600$ (d) (West 1977 \& Supp. 1984) (applicable to foreign corporation "having its principal executive office in this state or customarily holding meetings of its board in this state"). 
detailed business information from the corporation, they demanded to inspect the shareholder records. The corporation's management alleged that the demand for the shareholder list was part of a strategy to harass the company's management, motivated by the plaintiffs' competing business interests. ${ }^{159}$ In any event, it is hard to argue that two founding stockholders of a five-stockholder corporation were not participants in the creation of the other stockholders' expectations that the company would be subject to the statute under which it was incorporated, which was Delaware, or that the results of California's regulation of interstockholder relationships through section 1600 are self-evidently superior to those of the Delaware approach.

The final consideration under commerce clause analysis is the relative weight of the burdens imposed by these conflicting obligations and the legitimate local benefits yielded by the outreach doctrine. Both Valtz and Wilson emphasize that the corporations in those cases were unable to demonstrate any impact on their businesses or interstate transactions resulting from California's claim to regulate their internal affairs. But this focus seems unduly and inappropriately narrow. An assessment of the relative burdens and benefits produced by corporation statutes should take into account the uncertainties and resulting costs that conflicting regulation imposes on the corporation in planning and attempting voluntarily to conform its behavior to the law, as well as the costs or burdens that may be apparent only after litigation occurs. Corporations are, from the formal standpoint of state corporation statutes, creatures of paper: "The 'corporation' itself is born, lives, and dies all by and upon paper; when it eats, sweats, emotes, gets buried-'it' emits paper." 160 Subjecting a corporation to the strictures of conflicting corporation statutes requires the production of more paper, and more expensive paper at that. Thus, the relevant concern is not simply the impact of the regulation on the corporation's business transactions, but rather the impact on its total costs of operating under conflicting regulatory obligations. ${ }^{161}$ Costs such as additional attorney's

159. See Brief for Appellants at 2-8, Valtz v. Penta Inv. Corp., 139 Cal. App. 3d 803, 188 Cal. Rptr. 923 (1983). Facts like these cast doubt on the assumption that statutes which do not condition inspection on a showing of "proper purpose" are more "stringent" or "protective" than those which do. See Latty, supra note 14 , at $162 \&$ n.113. As the facts of Valtz suggest, statutes that confer an unqualified right to inspect may operate to "protect" the interest of one shareholder faction at the expense of injury to other shareholders or to the company's business activities.

160. Latty, supra note 79 , at 601 .

161. One authority has argued that a guiding principle in applying the commerce clause to questions like these is that when more than one state has an interest in the application of its law, the Court should apply the law which would best facilitate interstate commercial transactions. See Horowitz, The Commerce Clause as a Limitation on State Choice-of-Law Doctrine, 84 HARv. L. REv. 806, 814 (1971). Under this test, internal affairs questions arising in corporations with widely dispersed stockholders should be subject to the law of a single jurisdiction. Id. at 814-19. This jurisdiction need not be the state of incorporation, however, which may not have a "significant interest in having its policy prevail, if no members or shareholders reside there, and if no corporate business is done there." Id. at 819-20. But these factors for justifying the application of the law of a state other than that of the state of incorporation slight the formal and contractual significance of the decision to incorporate in a particular state. See supra text accompanying notes $74-75,89$. 
services for advice regarding the corporation's position under the California statute should be pertinent.

More ephemeral, perhaps, are the local interests furthered by outreach doctrines. In some respects, the California courts appear to assume that the application of California substantive law, in itself, is a worthy social good, even in the face of conflicting applicable law from other jurisdictions. ${ }^{162}$ This assumption is especially untenable when applied to statutes that purport to regulate activities occurring outside the state or affecting non-California residents. In addition, it is difficult to justify as a "legitimate local interest" the strategy of reducing the attractiveness of out-of-state incorporation through choice of law doctrines, particularly those that purport to regulate the non-California activities of corporations that are far from being true pseudo-foreign entities. Further, the ease with which some of the mandatory provisions may be evaded vitiates the strength of California's local interest in the imposition of the corporate rules made applicable to foreign corporations through section 2115 . If the statutory mandate of cumulative voting may be easily avoided by the device of using different classes of stock, it is hard to see why California has an especially strong claim to have its cumulative voting rule applied to foreign corporations too hapless to have evaded the requirement. Likewise, the permissibility of insurance reduces the strength of the asserted local interest behind the strict indemnification rules, as does the statutory exception from section 2115 for corporations registered on national stock exchanges. Avoiding some of these rules might reduce the burden their imposition creates for foreign corporations, but the burden is, perhaps, not entirely eliminated: determining that a corporation is subject to a rule, determining that the rule may be evaded, and then executing the evasion all represent "more paper"-increased costs to the corporation in a field of the law that is largely enforced through private planning and accommodation.

\section{B. Full Faith and Credit to State Interests and Parties' Expectations}

The full faith and credit clause, in conjunction with the due process clause, provides a further constitutional dimension to the outreach doctrines. Section 1 of article IV provides that "full faith and credit shall be given in each state to the public acts, records, and judicial proceedings of every other state," 163 and the fourteenth amendment prohibits states from depriving persons of "life, liberty, or property, without due process of law." 164 These sections suggest two questions about outreach doctrines and statutes: first, do these clauses permit the application of an outreach statute as local law by a court in the enacting jurisdiction or do they prohibit this application as an unconstitutional affront to the law of the state of incorporation; and second,

162. Cf. Hall v. Superior Court, 150 Cal. App. 3d 411, 197 Cal. Rptr. 757 (1983) (holding in part that contractual choice of law provision violated state policy against permitting waivers that made inapplicable California's Corporate Securities Law).

163. U.S. Const. art. IV, \& 1 .

164. U.S. Const. amend. XIV, \& 1 . 
do these sections require that courts of other jurisdictions-such as the state of incorporation-apply the outreach statute in preference to the corporation law of the state of incorporation?

In its application of both of these clauses to choice of law questions, the Supreme Court has examined the sufficiency of the contacts between the state whose law was applied and the parties and events involved in the litigation, requiring the choice of the law of states with "a significant contact or significant aggregation of contacts, creating state interests, such that choice of its law is neither arbitrary nor fundamentally unfair." 165 Only very rarely, and in extreme circumstances, has the Court invalidated a forum's decision to apply its own state's law to a controversy. ${ }^{166}$ Thus, the answer to the second question set forth above is quite likely to be that application of the outreach statutes by courts of other states is not constitutionally mandated, at least so long as the state whose law is applied has some contact with the corporation. Incorporation should suffice to create such a contact. ${ }^{167}$

The answer to the first question turns on whether the state whose outreach statute is applied has sufficient contacts with the parties and occurrences in the lawsuit to make application of its law "neither arbitrary nor fundamentally unfair." The Court interpreted the full faith and credit and due process constraints on choice of law recently in Allstate Insurance Co. v. Hague. ${ }^{168}$ In a plurality opinion, the Court upheld the Minnesota Supreme Court's choice to apply a Minnesota insurance rule permitting "stacking" of uninsured motorist coverage amounts to an accident case with which, although Minnesota had contacts, Wisconsin had more numerous and obvious contacts. Decedent was a Wisconsin resident as were the operators of both motor vehicles involved in the accident in which decedent met his death as a passenger, and decedent's insurance policies were delivered in Wisconsin. ${ }^{169}$ The Minnesota contacts identified by the Court as sufficient to justify selection of Minnesota law by the Minnesota Supreme Court were that decedent worked in Minnesota and commuted there daily (although the accident did not occur while decedent was commuting to work), that decedent's insurance company did business in Minnesota, and that decedent's surviving spouse moved to Minnesota prior to beginning the litigation. ${ }^{170}$ Minnesota, held the Court, "had a sufficient aggregation of contacts with the parties and the occurrence, creating state interests, such that application of its law was neither arbitrary nor fundamentally unfair." 171 The contacts between a foreign corporation and a

165. E.g., Allstate Ins. Co. v. Hague, 449 U.S. 302, 313 (1981).

166. E.g. Home Ins. Co. v. Dick, 281 U.S. 397 (1930).

167. For example, in Shaffer v. Heitner, 433 U.S. 186 (1977), although the Court invalidated Delaware's sequestration procedure as a basis for Delaware's assertion of personal jurisdiction over the defendants, it recognized the propriety of applying Delaware law to substantive issues concerning officers' and directors' liability in the action. Id. at $215 \&$ n.44.

168. 449 U.S. 302 (1981).

169. Id. at 305-06.

170. Id. at 313-19.

171. Id. at 320 . 
state required to trigger the outreach doctrines appear well within the sufficiency of state contacts sanctioned by Hague.

One obvious consequence of the Court's liberality in Hague is that more than one state might be able, from the perspective of the full faith and credit clause, to apply its corporate law constitutionally to the internal affairs of a particular corporation. ${ }^{172}$ Although the conflicts that can readily result from the overlapping application of state corporate statutes may be objectionable under the commerce clause, the question remains whether the same conflicts would be similarly troublesome under the full faith and credit clause. The only intimation that the full faith and credit clause mandates a choice of law approach that results in a uniform or at least consistent set of legal rules applicable to the internal affairs of business organizations appears in early twentieth century cases dealing with fraternal benefit societies. In those cases, the Court took the position that the validity of bylaws and organizational acts affecting members' rights and duties must be determined by the law of a single state in light of the complexity of the relationships created by such a fraternal organization. ${ }^{173}$ The reasoning in these cases, however, appears to have been influenced by the view of choice of laws that placed great emphasis on a state's territorial connection with events and persons, ${ }^{174}$ a view many now regard as anachronistic. ${ }^{175}$ In any event, the Court's more contemporary readings of the full faith and credit clause do not echo the necessity for uniformity found in the fraternal benefit cases, although differences in subject matter rather than in doctrine may well explain this failure. ${ }^{176}$

The remaining relevance of the full faith and credit clause to these questions stems instead from its mandate that states give recognition to

172. Delaware's Supreme Court has acknowledged this possibility pessimistically. See Armstrong v. Pomerance, 423 A.2d 174, 177 (Del. 1980) (upholding constitutionality of statute treating acceptance of directorship in Delaware corporation as consent to suits in Delaware arising out of such service).

173. See, e.g., Modern Woodmen of Am. v. Mixer, 267 U.S. 544, 551 (1925); Supreme Council of the Royal Arcanum v. Green, 237 U.S. 531, 542-43 (1915).

174. See, e.g., Modern Woodmen of Am. v. Mixer, 267 U.S. 544, 551 (1925) ("The act of becoming a member is something more than a contract-it is entering into a complex and abiding relation-and as marriage looks to domicil, membership looks to and must be governed by the law of the state granting the incorporation."). The Court used the same reasoning in Broderick v. Rosner, 294 U.S. 629, 643-44 (1935), to invalidate a New Jersey statute that would have barred the use of the New Jersey courts to enforce assessments against shareholders made under the statutory directives of another state. Indeed, Broderick speaks of the stockholders' "voluntarily assumed statutory obligation," id. at 644 , created when they became stockholders, which makes their liability "contractual in character." Id. at 643.

175. See, e.g., E. Scoles \& P. Hay, Conflict of Laws 13-15 (1982).

176. One suggestion that the Court may continue to regard uniformity as a necessary aspect of regulation of corporate internal affairs appears in Shaffer $v$. Heitner. After acknowledging that Delaware law could properly be applied to the substantive questions in the action, the Court observed that generally the law of the state of incorporation is held to govern the internal affairs of corporations and that while section 2115 of the California Corporations Code is to the contrary, " $[t]$ he rationale for the general rule appears to be based more on the need for a uniform and certain standard to govern the internal affairs of a corporation than on the perceived interest of the state of incorporation." 433 U.S. at $215 \mathrm{n} .44$. Unlike the old fraternal benefit cases, however, this statement may not accredit the need for uniformity with a constitutional basis and it may suggest that the need for uniformity varies with the nature of the controversy. 
judgments entered in courts of other states. Assuming that the court issuing the judgment properly had jurisdiction over the parties and the controversy, the full faith and credit clause ensures that foreign courts' judgments will be recognized by other states. ${ }^{177}$ As applied to the outreach statutes, this aspect of full faith and credit dogma reduces all original questions essentially to a race to the courthouse-the first plaintiff to obtain personal jurisdiction over the relevant defendants and a judgment in the forum with the version of corporate law favoring his side of the dispute should prevail in the face of litigation over the same controversy in other jurisdictions. ${ }^{178}$

The result is that the law applicable to a question of corporate internal affairs may well turn on where an action is brought to resolve the question through litigation. A key question is whether this result is any more vexing or problematic for questions of corporate law than for other areas of the law, in which the outcome of litigation also appears in many instances to turn on its location. ${ }^{179}$ Indeed, there are aspects of the functions assumed by corporate laws which make this result troublesome.

First, corporation statutes are applied, and complied with, without resort to litigation, except in very rare instances. Persons associated with the corporation determine the requirements of the statutes through private lawyers' opinions, rather than through litigation. An approach suggesting that conflicts among corporation statutes can be resolved through litigation in a sympathetic forum thus appears to be oblivious to the minimal role that litigation plays in compliance with corporation statutes. Indeed, the subject matter of much corporate law litigation-shareholders' liability for corporate debts, authority of purported corporate agents to bind the entity, successor corporations' liability for predecessor corporations' obligations, the propriety of fiduciaries' activities-is not addressed by the outreach statutes. Second, many of the topics that are dealt with by the outreach statutes involve recurrent matters rather than isolated events and ongoing relationships rather than one-shot encounters. Rules prescribing methods of shareholder voting, for example, must be applied for each shareholder meeting. Thus, the number of times in which participants in a corporation may need to determine the applicable law could be considerable, in contrast with more typical one-event situtations (like automobile mishaps) in which choice of law predicaments also arise. Third, resolving uncertainties about the applicable corporate law rule through litigation is not free because, win or lose, the corporate defendant pays its own attorney fees. Even "winning" imposes these and other costs of litigation on the corporate defendant in most instances. Ultimately, these

177. See E. Scoles \& P. Hay, supra note 175, at 933-34.

178. In one California case, for example, a California Superior Court first held in an unreported decision that section 2115 of the California Corporations Code was unconstitutional on full faith and credit and commerce clause grounds in its regulation of the voting practices of foreign corporations. A Delaware court in the same litigation subsequently held that in light of the California court's determination, Delaware law applied. See H. Henn, Laws of Corporations $222-23$ n.54 (1983).

179. See B. Currie, The Constitution and the Choice of Law: Governmental Interests and the Judicial Function, in Selected Essays on the Conflict of Law 188, 281 (1963). 
costs are borne by all of the corporation's stockholders, many of whom might well assume that the corporation's internal affairs are governed by the law of the state of incorporation, or at least might prefer that they be, given the cost of the alternatives.

One question left unaddressed by the plurality opinion in Hague is whether express or implicit indications of the parties' intentions should be given weight in assessing the constitutionality of choice of law determinations. Although Justice Stevens' concurring opinion in Hague intimated that a court's choice of law may violate the due process clause because it frustrates "the reasonable expectations of the contracting parties," 180 no express or implicit indication of the parties' expectations about the law that would govern their relationship appeared in the facts of that case. Indeed, the insurance policies involved in Hague covered accidents throughout the United States, ${ }^{181}$ suggesting that the parties did not have an exclusive expectation that the law of any one state would govern claims made under the policies. One might well wonder whether the choice to incorporate in a particular state should be viewed in this framework as an indication of the parties' contractual intention that they (and their successors as shareowners) be bound as to internal affairs questions by the corporation law of that state, and if so interpreted, whether this statement of intention is protected by notions of due process.

The Court in 1985 further explored the constraints imposed on states' choice of law decisions by the due process and full faith and credit clauses in Phillips Petroleum Co. $v$. Shutts. ${ }^{182}$ Although the Court upheld the constitutionality of the Kansas class action statute applicable to nonresident plaintiffs in a nationwide class action to recover interest on delayed royalty payments, it held that the determination by the Supreme Court of Kansas that Kansas law applied to all plaintiffs' claims was so arbitrary and unfair as to exceed constitutional limits on choice of law. ${ }^{183}$ In the Court's view, Kansas lacked sufficient contact with the plaintiffs' claims to justify application of its law because $99 \%$ of the gas leases involved in the litigation and $97 \%$ of the plaintiffs lacked any connection with Kansas apart from the litigation and because the law of other states connected with the litigation-notably Texas and Oklahoma-arguably conflicted with Kansas law. ${ }^{184}$ Further, the Court disparaged the argument that members of the plaintiff class, by not opting out of the lawsuit, consented to the application of Kansas law, noting that the plaintiffs' desire for forum law is not dispositive; nor did the fact that Kansas was adjudicating a nationwide class action enhance its ability to apply its own law. An aspect of fairness singled out by the Court's opinion is the parties' expectations: in the context of the events underlying the litigation, the parties had "no idea that Kansas law would control," making the subsequent

180. 449 U.S. at 330 (Stevens, J., concurring).

181. Id. at 329 .

182. 53 U.S.L.W. 4879 (U.S., June 25, 1985).

183. Id. at $4885-86$.

184. Id. at 4884-85. 
application of Kansas law unfair. ${ }^{185}$ Thus, Phillips Petroleum develops further the suggestion in Allstate Insurance that, although states have considerable latitude in choice of law determinations, parties' expectations can limit that discretion.

To be sure, the idea that the decision to incorporate is one that expresses contractual intentions and creates contractual expectations is far from pervasive in the case law and scholarly literature addressing the pertinent choice of law question. The interests on which this body of doctrine focuses are those of states, not private parties. ${ }^{186}$ In the California cases testing the constitutionality of section 2115 , therefore, the court's purview was limited to assessing against the interests of California in the enforcement of its mandantory statutory provisions, the lesser interests of the state of incorporation. In Valtz, for example, the court examined whether the satisfaction of California's interest in the enforcement of its provision granting unqualified access to shareholder lists would require the corporation to violate Delaware law, determined that it would not, and concluded further that no need for a uniform standard to govern the question had been demonstrated. ${ }^{187}$ This analytic approach evidently gives no weight at all to the parties' expectations or contractual interests created by the decision to incorporate in a particular state. Likewise, in Wilson, the court determined that California's interests in the application of its cumulative voting rule to foreign corporations outweighed the interests of Utah, the state of incorporation, concluding that Utah had "no interests which are offended by cumulative voting." 188

Idiosyncratic as the thought may be from the standpoint of the contemporary thinking about choice of law, ${ }^{189}$ these cases might simply ask the wrong question; perhaps the "interests" properly to be vindicated in these disputes are those represented by the contractual choices of private parties rather than the governmental interests of the state. Valtz and Wilson involve disputes among groups of shareholders and managers, and only a curiously disembodied view of such litigation understands it to concern conflicts among sovereign states rather than private parties. ${ }^{190}$ Focusing on which state is

185. Id. at 4886 .

186. For example, Professor Kirgis analyzes the propriety of statutes like section 2115 of the California Corporations Code in terms of which state has a greater interest in resolving matters such as internal affairs questions. See Kirgis, supra note 1, at 141 (referring to "overwhelmingly interested" state in contrast to state of incorporation); cf. Anderson, The Meaning of Federalism: Interpreting the Securities Exchange Act of 1934, 70 VA. L. REv. 813 (1984) (discussing difficulties in defining states' interests).

187. 139 Cal. App. 3d at 808, 188 Cal. Rptr. at 925.

188. 138 Cal. App. 3d at 223, 187 Cal. Rptr. at 857.

189. But see Kozyris, Corporate Wars and Choice of Law, 1985 DukE L.J. 1.

190. The nagging sense that, after all, perhaps writers in this area have been asking and answering the wrong question-wrong in the sense of beside the point-was well expressed (albeit in a different context) by H.A. Prichard in his 1912 essay, "Does Moral Philosophy Rest On A Mistake?" Prichard wrote:

Probably to most students of Moral Philosophy there comes a time when they feel a vague sense of dissatisfaction with the whole subject. And the sense of dissatisfaction tends to grow rather than diminish. It is not so much that the positions, and still more the arguments, of particular 
"interested in" or has the "greater interest" in regulating such matters ignores the fact that the occasion for any state's interest in such questions stems from the prior choices of private parties and undercuts the significance of those choices.

Even if the question to be addressed is the respective interest of various states in the application of their corporation statutes to a particular controversy, a somewhat different casting of state or governmental interest is appropriate. A strong governmental interest ignored by cases like Valtz and Wilson and by much of the academic literature on this topic is the interest of the state of incorporation in the enforcement of private parties' agreements that are permitted or validated by that statute. Of course, to recognize such an interest as decisive or even weighty is to recognize and validate the overwhelmingly private nature of the realm of corporate law, but to do so would be consistent with the highly contractualized view of corporation law that dominates the contemporary view of the subject.

Finally, one might wonder about the appropriate forum for this "recognition." The late Brainerd Currie argued forcefully that the Supreme Court should not choose the asserted interest of one state over that of another, apart from determining whether an asserted state policy had any validity or constitutional significance. In Currie's view, to make such a choice was properly the function of Congress. ${ }^{191}$ Thus, if it is conceded that states with outreach statutes have any valid interest in their application, should the decision to subordinate that interest to the interests of the state of incorporation be left to Congress? One might, of course, argue that the state interests created in the state of incorporation by the parties' decision to incorporate there are self-evident (and perhaps sui generis) trump cards that can be furthered without doing violence to a proper conception of the judicial function. Alternatively, the Court might conclude that the statutory predicates for applicability of the outreach provisions, which in each statute are geared to whether the corporation is "doing business" in the state, are insufficiently connected to the internal affairs provisions imposed on foreign corporations to create any valid state interest. A final possibility for the resolution of these difficulties is the enactment of a federal corporation statute to displace state corporate laws, at least on the points at which they are in

thinkers seem unconvincing, though this is true. It is rather that the aim of the subject becomes increasingly obscure. 'What', it is asked, 'are we really going to learn by Moral Philosophy?' 'What are books on Moral Philosophy really trying to show?, and when their aim is clear, why are they so unconvincing and artificial?' And again: 'Why is it so difficult to substitute anything better?' Personally, I have been led by growing dissatisfaction of this kind to wonder whether the reason may not be that the subject, at any rate as usually understood, consists in the attempt to answer an improper question. And in this article I shall venture to contend that the existence of the whole subject, as usually understood, rests on a mistake

See H.A. Prichard, Does Moral Philosophy Rest On A Mistake?, in Moral Obligation: Essays and LECTURES 1 (1949).

Prichard's "vague sense of dissatisfaction" seems to be an irresistible response to attempts to elicit and compare state interests in the regulation of corporate internal affairs, perhaps precisely because these efforts are directed to the wrong question.

191. See B. Currie, supra note 179, at 277-78. 
conflict. The content of any federal statutory solution, however, would not necessarily be consistent with those statutes in the countercultural tradition discussed above, for, oddly enough, the political impetus toward federal incorporation as a response to conflicting state statutes could more likely than not be dominated by corporations resisting the embrace of outreach provisions.

\section{VI}

\section{ConCLUSION}

Although the preceding discussion suggests that outreach statutes may be problematic from the standpoint of both the commerce clause and the full faith and credit clause, the analysis under each clause tends to emphasize different factors and to proceed with a slightly different focus. While the commerce clause analysis concentrates on the observable effect of the statute in place, that is, on the burdens imposed on interstate commerce and the local benefits generated by the regulation, the full faith and credit perspective is more abstract, examining the validity of the interests of a given state in having its law apply to a particular situation. Thus, it is conceivable that, even if some valid state interest supports the application of a state's law under the full faith and credit analysis, the actual effects of that application might burden interstate commerce disproportionately to the local benefits produced, so that the law would be invalidated by the commerce clause. Likewise, aspects of outreach regulation assume different significances under the two analyses. For example, the fact that the impact of some mandatory aspects of a corporation statute can be evaded through legal bylaw and charter provisions is, from the standpoint of the commerce clause analysis, probably a neutral factor. Although the fact that some such requirements can be avoided suggests that the burden they impose on interstate commerce may not be too great, the costs of designing and executing the evasive mechanisms should also be relevant to commerce clause analysis. On the other hand, under the full faith and credit analysis, the possibility that a requirement may legally be evaded by a domestic corporation or a foreign corporation subject to an outreach statute vitiates the force of a state's claim that imposition of the requirement to any foreign corporation is supported by strong local policy concerns.

Apart from general constitutional challenges to all aspects of outreach statutes, it is evident that the vexations (constitutionally offensive and otherwise) created by such statutes vary depending on the range of corporations to which they are applicable and the nature of the local corporate law provisions imposed on foreign corporations. Applying local law to the "truly pseudo-foreign" corporation that has all its business dealings in that state and all stockholders resident there, is in practical terms a different proposition from the application of local law to a foreign corporation with some local contacts accompanied by dispersed business activities and stockholders. In the first instance, the stockholders might even fairly 
anticipate that local law could be applicable to their corporate relationships, while that expectation seems less likely for the less locally concentrated enterprise.

The functional impact of applying various aspects of local corporate law to foreign corporations also varies greatly. Whether the application of local law affects only the validity of one transaction or the validity of the internal corporate mechanisms which govern many transactions is relevant. Applying local law to determine the effectiveness of a (locally resident) stockholder's grant of an irrevocable proxy to another person to vote his stock, for example, is less likely to be troublesome than applying local law to assess the validity of a corporate bylaw dealing with voting or share transfers. The first application of local law affects one transaction which amounts to a private noncorporate action of one stockholder, while the second application may affect many transactions, some which may not have any local connections. Likewise, aspects of local corporate law the primary significance of which arises in the context of litigation-such as controls on the indemnification of defendants' litigation expenses-seem less disruptive as applied to foreign corporations than do corporate law provisions that do not typically emerge in litigation, such as shareholder voting rules. True, contested shareholder meetings and elections may result in litigation, but the bulk do not, and compelling resort to litigation to determine the applicable voting structure is for that reason not appealing.

Finally, a state's claim to apply local law to foreign corporations seems strongest when the matter to be regulated directly affects the interests of local creditors, as does the legal propriety of dividends. The claim is least strong where only the relationships of stockholders inter sese are implicated. Outreach statutes are most likely to be constitutionally inoffensive to the extent that they purport to regulate only "truly pseudo-foreign" corporations and to the extent that the provisions of local law made applicable to foreign corporations are those implicating the interests of local creditors or regulating isolated events and intrastate transactions. 